\title{
金属焼付ポーセレン冠の適合性に関する研究
}

一歯頸部辺縁形態ならびに陶材被覆形態について一

宮内修平

\section{Studies on the Adaptation of Porcelain-Fused-to-Metal Crown}

- Effect of the Types of Cervical Margin and the Degrees of Porcelain Coverage -

\author{
Shuhei Miyauchi
}

\section{緒 言}

歯冠補緅の目的は, 歯牙の解剖学的形態, 生理学的機 能および審美性を正常に回復し, その状態を維持するこ とである.この見地に立つて支台歯と補緅物の関係を考 えるとき，良好な適合性を得ることが不可欠であり，こ の適合性に大きな影響を及ぼす因子として，支台歯形態 および補緅物の形態が挙げられる.

金属焼付ポーセレン冠は, 審美的かつ力学的に優れた 補維物として広く臨床に用いられているが，辺縁歯肉の 変色, 炎症などの病的変化や陶材の破折が予後の重要な 問題 ${ }^{1,2)}$ としてとり挙げられている. 歯肉の変化は, 生物 学的見地からみると, セメントや焼付用合金の組織為害 性により起るものと考えられ，一方理工学的見地からみ ると，冠辺縁の不適合による影響が考えられる．歯肉変 化と歯頸部の適合性との関連性について, 丸山ら ${ }^{3)}$ は, 金属焼付ポーセレン冠の予後観察の結果から, 適合状態 が不良と思われるものには歯肉炎の充進が著明であつた と述へててい. 他方, 力学的見地から, 適合が良好な冠 に比へて不良なものは，咬合力などによる金属の歪みが 生じやすく，冠の変形や破損ことに陶材の破折をひき起 しやすいと考えられる．以上のように適合性が金属焼付 ポーセレン冠の予後に大きな影響を及ぼすことが考えら れ，良好な適合を得るための最善の努力が払われなけれ

\footnotetext{
大阪大学歯学部菌科補緅学第 1 教室（指導：下総高次教 授)

1st Department of Prosthetic Dentistry, Osaka University Dental School. (Director: Prof. Takaji Simoosa) 炤和 51 年 1 月 15 日受付
}

ばならない，なお，全部鋳造冠の適合性に関しては，す でに多くの事奏が明らかにされている. しかし，金属焼 付ポーセレン冠は, 陶材焼付けを行う点で全部鋳造冠と は本質的に異なつており，その適合性については未だ十 分に解明されていない.

支台歯における歯顽部辺縁形態の種類は, shoulder, bevel, chamfer, knife edge, beveled shoulder など が举げられ，それら辺縁形態の差異によつて適合性が異 なることは, 全部鋳造冠に関してはいくつかの報告4,5) があり, 一応の結論は得られたように思われる.しか し，金属焼付ポーセレン冠に関しては，歯顧部辺縁形態 に注目して冠の適合性を論じた報告はほとんどなく，わ ずかに Shillingburg6) らが辺縁形態と冠の変形に関して 検討しているにすぎない.

一方, 金属焼付ポーセレン冠の陶材被覆の形態は, 大 別して veneer type と full bake type であるが, 従来主に veneer type の方法が用いられてきた. しか し，最近の臨床においては，陶材破折防止やいつそう優 れた審美性を得ることを目的として，陶材を舌側歯頸部 の位置まで焼成した full bake type の方法8,9) が用い られつつある.これら陶材被覆形態に関寸る基脴的研究 として，破折強度に関する報告 ${ }^{10,11) か ゙ わ す ゙ か に み ら れ る ~}$ が，その形態が適合性に及ぼす影響についての報告は全 くみられない。

そこで本研究は，支台歯に対する人工歯冠の良好な適 合条件を確立することを目的として，金属焼付ポーセレ ン冠について, 鋳造, degassing, 陶材焼付け, セメント 合着にわたる各操作過程における適合度の変化を究明 し，歯頸部辺縁形態ならびに陶材被覆形態の差異が冠の 適合性に及ぼす影響を検討するとともに，陶材焼成によ 

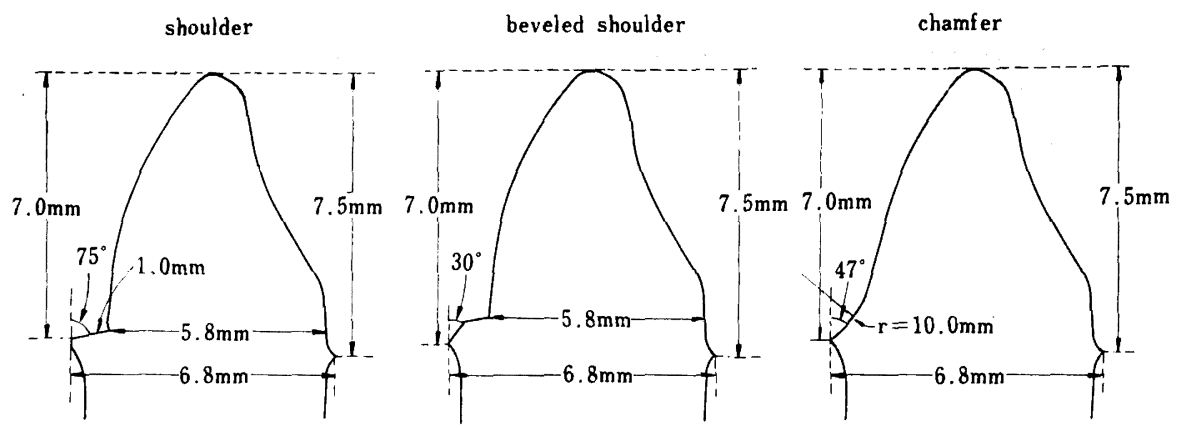

(側面图)
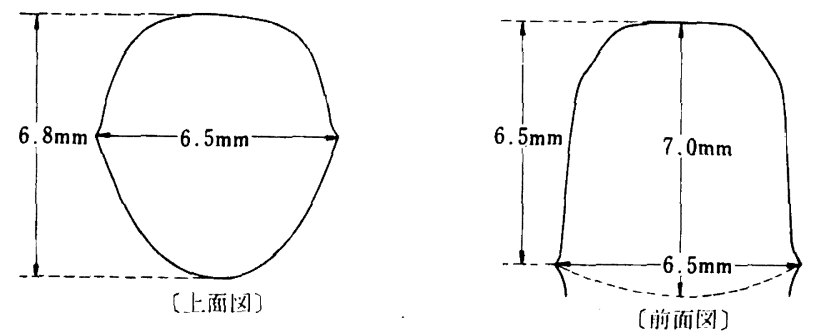

図 1 支台迷の形態および寸法

り発生する応力および唇面歯頸部辺縁形態別の変形抵抗 性について検討を加えた.

\section{実験試料ならびに方法}

\section{I. 試料の製作}

\section{1. 支台僯の製作}

金属焼付ポーセレン冠の臨床における適志範用として は，上顎前歯部が最も多いことから，本実験において は，上顎中切歯支台歯模型を実験対象に選択した，歯頸 部辺縁形態は，それぞれ shoulder type, beveled shoulder type, chamfer type の 3 種類とした. 支台歯の 寸法は, 藤田 ${ }^{12)}$, 上条 ${ }^{13)} ら$ 天然歯牙の寸法計測值, お よび増田ら ${ }^{14)}$ の雬牙可削径の計測值と Johnston ${ }^{15}$ ?らの 支台歯形成法を参考にして決定した（図 1). 本実験で は，支台歯材料として同一規格の支台歯が製作出来，硬 度が象牙質と近似しているエポキシ樹脂を使用した。象 牙質とエポキシ樹脂の硬度 ${ }^{16)}$ と表面あらさは表 1 に示 す.

\section{2. コーピングの製作}

i. ワックスパターンの製作

コーピングとして，同一規格の形態を得るため，ワッ クスパターン採得用の鋳型を製作した.コーピンク゚の形 態および寸法は, Straussberg17) や Mumford ${ }^{18)}$ の提唱
表 1 象牙闻とエボキシ杫脂の硬度および表面あらさ

\begin{tabular}{|c|c|c|}
\hline & 硬 惟 (Hv) & 长湎あらさ \\
\hline 象分 & $33-36$ & $\begin{array}{l}H \max 2-3 \mu \\
\text { Ha. } 0.3-0.5 \mu\end{array}$ \\
\hline エポキシ樹脂 & $22.5-38.3$ & 0 \\
\hline
\end{tabular}

する方法に準じて決定した.コーピングの形態は,歯頸部 辺縁において shoulder type, beveled shoulder type, chamfer type の 3 種類とし, それぞれ veneer type, full bake type の 2 種類の陶材被覆形態を付与し, 計 6 種類とした (図 2).

ワックスパターン採得用鋳型の製作は, Dunkin ${ }^{19)}$ の 鋳型製作法を参考にした. まず，上記形態のワックスパ ターンを形成し，ワックスの流入孔および流出孔を付与 した後, 支台歯ごと円錐台に植立した.つぎに，シリコ ーンラパー印象材 (Jelcone Injection type) を植立模 型に注入し，その陰型を鋳型とした.

ワックスパターン採得は, 軟化溶融ワックスをシリン ジにて注入することによつて行つた. すなわち, G-C 社 製バイオレットインレーワックス ${ }^{20)}$ を満たしたシリンジ を $63^{\circ} \mathrm{C} \sim 65^{\circ} \mathrm{C}$ に保温したウォーターバス中に保ち, ワックスを軟化溶融させたのち，ただちに流入孔より鋳 型内に注人を行つた. ワックス硬化後, 鋳型から支台畨 ごと取り出し, 成形を行つた.そして, そのまま室温中 


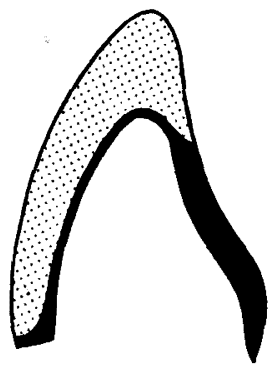

veneer

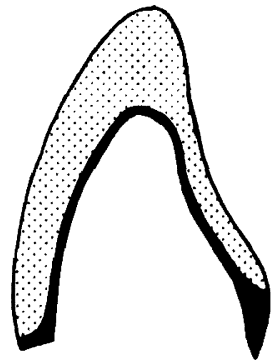

full bake

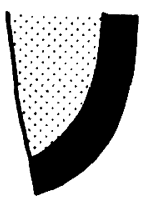

chamfer shoulder beveled shoulder

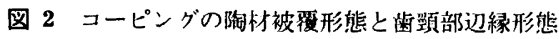

$\left(22^{\circ} \mathrm{C} \sim 25^{\circ} \mathrm{C}\right)$ に 24 時間放置した. ワックスは, 軟化溶 融して用いれば必ず収縮するものであるが，内部応力を 解放するためには室温中で24時間放置することが必要で

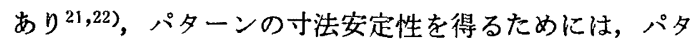
ーン調整後少なくとも 1 時間以上，できれば 1 日ぐらい 室温中で静置しておく必要がある ${ }^{23)}$ といわれる，そのた め, 本実験においては, ワックスパターン調整後, 室温 中で 24 時間支台歯上に静置しておいた.

ii. 埋 没

ワックスパターンの舌側に直径 $1.8 \mathrm{~mm}$ の中空スプ ルー線を, また唇側切端 $1 / 3$ の所に直径 $1.0 \mathrm{~mm}$ のレデ イキャスティングワックスのエアーベントを付与し，埋 没準備を行つた. ワックスパターンに表面活性剤を塗布 したのち乾燥し, 混液比 0.16 の Whip-Mix 社製 Ceramigold Investment（Lot. 0375401）を用い，専用液濃 度を $75 \%$ とし，スパチュラにて 10 秒間練和後, 大気中 で埋没を行つた. なお，埋没は鋳造リングによる埋没材 の膨張抑制を防止する目的でリングレス ${ }^{24 ~ 29)}$ 方法で行 った. 以上の操作は, すへて室温中 $\left(23^{\circ} \mathrm{C} \sim 25^{\circ} \mathrm{C}\right)$ で行 つた.

\section{iii. 乾燥, 焼却}

埋没材の表面あらさは，埋没材の放置時間を長くする ほど小さくなる傾向がある汪)ということから，埋没後の 放置時間は 24 時間とした. その後, 鋳造用鋳型を電気 炉（大栄社製オートファーネス model 1000）内に移し, 乾燥, 加熱を行つた. 加熱は室温から $700^{\circ} \mathrm{C}$ まで 2 時
間で行い, $700^{\circ} \mathrm{C}$ で 30 分間係留した。

iv. 鋳 造

金属の溶解は，都市ガスと酸素の混合ガスを用い，ブ ローパイプで行つた．鋳造は，Torit 縦型遠心鋳造機を 使用し，バネの巻数は 2.5 回とした．金属は焼付用金合 金KIK（石福金属社製）を使用し，各試料ごとに新しい 金属 $3 \mathrm{~g}$ を使用した．なお，予備実験で鋳込み時の金属 の温度測定を行つた結果, $1,265 \pm 10^{\circ} \mathrm{C}$ であつた. これ は KIK の融点の約 $10 \%$ 增しである ${ }^{30)}$ 。鋳造後，鋳型 は室温中で自然放冷した. 埋没材を除去し, $50 \%$ フッ化 水素酸水溶液中で 15 分間超音波洗浄を行つたのち， 20 分間蒸留水中で超音波洗浄を行つた. 鋳造体のスプル 一, ベント切断後, カーボランダムポイントを使用して 陶材焼付面全体を研摩し, フッ化水素酸水溶液中で再び 15 分間超音波洗浄を行つた.

\section{3. 陶材焼付け}

鋳造後の試料は，焼成条件に従つて degassing から glazing まで行つた（図 3 ).

i. degassing

鋳造後の試料について, degassing 操作を行つた. 通

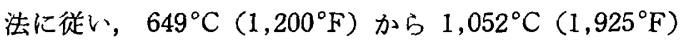
まで昇温速度 $24^{\circ} \mathrm{C} / \mathrm{min}\left(75^{\circ} \mathrm{F} / \mathrm{min}\right)$ とし, 減圧度は $-700 \mathrm{mmHg}$ で焼成し, $1,052^{\circ} \mathrm{C}\left(1,925^{\circ} \mathrm{F}\right)$ で 15 分間 係留後, ガラスコップ内で徐冷した.

ii. 陶材の築盛, 焼成

a. opaque 陶材の築盛, 焼成

degassing を行つた試料は, 陶材の築盛, 焼成を行つ た. 陶材は Ceramco B.F. Vacuum Porcelain を使

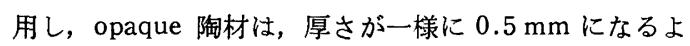
うに築盛し，十分にコンデンスを行つた、焼成は，予備 乾燥 10 分間後, $649^{\circ} \mathrm{C}\left(1,200^{\circ} \mathrm{F}\right)$ 加 $938^{\circ} \mathrm{C}\left(1,720^{\circ}\right.$ F) まで昇温速度 $24^{\circ} \mathrm{C} / \mathrm{min}\left(75^{\circ} \mathrm{F} / \mathrm{min}\right)$, 減圧度 -700 $\mathrm{mmHg}$ で焼成し, その後大気中で $993^{\circ} \mathrm{C}\left(1,820^{\circ} \mathrm{F}\right)$ まで焼成し，ガラスコップ内で徐泠した。

b. dentin, enamel 陶材の築盛, 焼成

通法に従つて, dentin, enamel 陶材を 1 回で築盛, 焼 成した. 築盛に際し, 唇面中央部で厚さ $1.5 \mathrm{~mm}$ にし, すへての試料が可及的に均一な寸法となるよう心がけ た. 焼成は, 予備乾燥 10 分間行つた後, $649^{\circ} \mathrm{C}\left(1,200^{\circ}\right.$ F) から $927^{\circ} \mathrm{C}\left(1,700^{\circ} \mathrm{F}\right)$ まで昇温速度 $24^{\circ} \mathrm{C} / \mathrm{min}$ $\left(75^{\circ} \mathrm{F} / \mathrm{min}\right)$, 減圧度 $-700 \mathrm{mmHg}$ で焼成し, その後大 気中で $982^{\circ} \mathrm{C}\left(1,800^{\circ} \mathrm{F}\right)$ まで㜔成し，ガラスコップ内 で徐泠した. 焼成を終えた試料は, 各々の支台歯に帍 し，歯冠部を万能投影機で投影し，あらかじめ用意して 


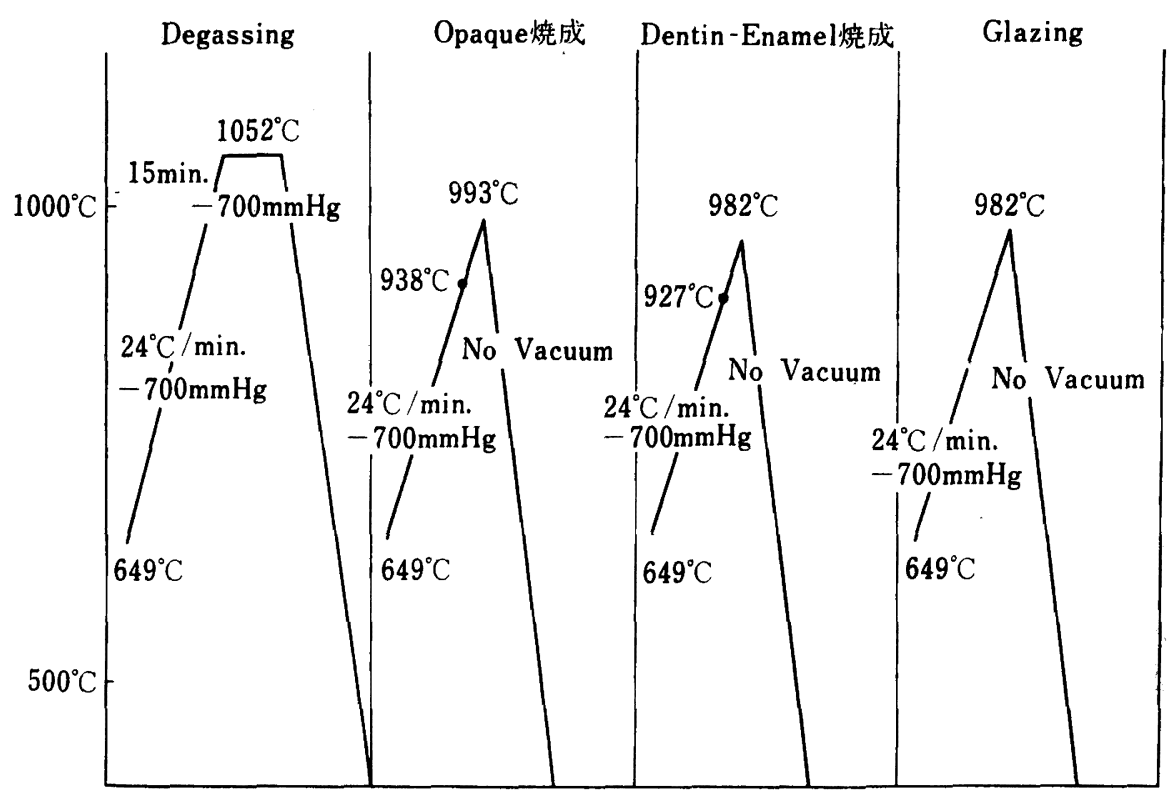

Room temperature

図 3 烧成スケジュール

おいたマスターモデルの歯冠部投影図と一致するように 細部の修正を行つた.

\section{c. glazing}

形態修正をほどこした試料はすべてについて glazing を行つた. 焼成は, $649^{\circ} \mathrm{C}\left(1,200^{\circ} \mathrm{F}\right)$ から $982^{\circ} \mathrm{C}\left(1,800^{\circ}\right.$ F) まで昇温速度 $24^{\circ} \mathrm{C} / \mathrm{min}\left(75^{\circ} \mathrm{F} / \mathrm{min}\right)$ で大気中で焼 成し，ガラスコップ内で徐泠した.

4. セメント合着

セメント合着による浮き上がりおよびセメント層の厚 さを知るため, 陶材焼付け完成した試料を松風マイク口 セメント（Batch No. 89）で合着した. 合着条件は, セメント練和比を $\mathrm{L} / \mathrm{P}=0.5 \mathrm{cc} / 1.47 \mathrm{~g}$ の標準稠度とし, 練和時間は 60 秒とした. セメント合着に際し, 荷重条 件は，医員 10 人による予備実験結果から決定した。す なわち, 上䫟前苗部における冠装着時の指圧を 10 人に ついて測定した結果, 平均值は $4.2 \pm 0.5 \mathrm{~kg}$ であつた. そこで, 本実験では練和開始より 10 分間 $4 \mathrm{~kg}$ 荷重を行 つた.なお，荷重量の判定には，日本光電社製咬合力測 定器を用いた. セメント硬化後, 余剩のセメントを除去 した.

\section{II. 測定方法}

試料数は, 鋳造後, degassing 後, 陶材焼付け後, 七 メント合着後の各段階で veneer lype につき歯頚部辺 縁形態の異なる 3 種類の試料を各 6 個ずつ 18 個と, full
表 2 䳝 料 数

\begin{tabular}{|c|c|c|c|c|c|c|}
\hline \multicolumn{2}{|c|}{ type 操作過程 } & \multirow{2}{*}{$\begin{array}{l}\text { as } \\
\text { cast } \\
6\end{array}$} & \multirow{2}{*}{$\frac{\text { degassed }}{6}$} & \multirow{2}{*}{$\begin{array}{l}\begin{array}{l}\text { porcelain } \\
\text { fused }\end{array} \\
6\end{array}$} & \multirow{2}{*}{ cemented } & \multirow{2}{*}{$\begin{array}{r}\text { total } \\
24\end{array}$} \\
\hline & shoulder & & & & & \\
\hline & $\begin{array}{l}\text { beveled } \\
\text { shoulder }\end{array}$ & 6 & 6 & 6 & 6 & 24 \\
\hline & chamfer & 6 & 6 & 6 & 6 & 24 \\
\hline \multirow{3}{*}{ bake } & shoulder & 6 & 6 & 6 & 6 & 24 \\
\hline & $\begin{array}{l}\text { beveled } \\
\text { shoulder }\end{array}$ & 6 & 6 & 6 & 6 & 24 \\
\hline & chamfer & 6 & 6 & 6 & 6 & 24 \\
\hline \multicolumn{2}{|r|}{ total } & 36 & 36 & 36 & 36 & 144 \\
\hline
\end{tabular}

bake type につき同様に 18 個とで, 計 36 個ずつ合計 144 個である（表 2 ).

それらの試料はそれぞれもとの支台歯に插入し, シア ノアクリレートで仮着固定し，エピコート樹脂で包埋し た. 樹脂硬化後, 切断器 ${ }^{31}$ にて各試料を唇舌的に長軸方 向で切断し，エメリー紙で近遠心中央部まで研摩し，最 後は切断面をバフで仕上げ研摩した（図 4).

測定は，切断面における冠と支台蒛との間隙を対象と し精度 $1 / 1,000 \mathrm{~mm}$ の Nikon 6C 型万能投影機を使用 し, 倍率 50 倍で行つた.

測定部位は図 5 に示す通り，Aは唇面歯頸外粶部〔支 
台歯唇面外縁から唇面に沿つて内方人 $0.3 \mathrm{~mm}$ の点了, B は唇面歯頸内側部〔支台歯唇面外縁から $0.7 \mathrm{~mm}$ 内 方の歯軸に平行な直線が唇面と交わる点了，Cは唇面軸 壁下部〔唇面中央部Dから唇面に沿つて下方へ $2.5 \mathrm{~mm}$ の点], $\mathrm{D}$ は唇面中央部, $\mathrm{E}$ 《切端部, $\mathrm{F}$ 活舌面中央部, G は舌面歯頸部〔支台歯舌面外縁から舌面に沿つて内方 人 $0.3 \mathrm{~mm}$ の点]とする. 以後, 測定部位は, 主に A, B ‥G G 記号で表わすことにする，当該測定部位における 冠と支台歯閒の距離をもつて間隙量とする.

III. 陶材焼成により発生する応力の測定と唇面蒾頸 部辺縁形態別の変形抵抗性に関する有限要素法 による数値計算

1. 陶材焙成により発生する応力の測定

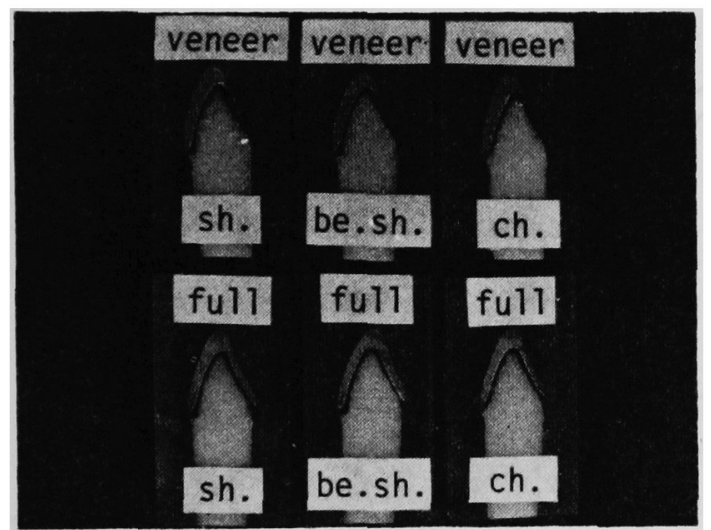

図 4 試料の切断面

上段: veneer sh. : shoulder 下 段: full bake ch. : chamfer
陶材狫成により応力一ひずみの関係が生じ，金属体が 変形すると考えられる.そこで，陶材焼成によつて冠に 生じる応力を知る目的で，まず基整的に金属平板に陶材 を焼き付けたものについて，歪ゲージを使用し，陶材を 逐次除去することにより，陶材内の残留応力を測定，検 討した。

材料は，本実験使用の金属 KIK と陶材 Ceramco B.F. Vacuum Porcelain を用い，歪ゲージは直角配置型䇴歪 ゲージ（共和電業社製，KFC-2-D, 17-11）を使用した.

まず，パラフィンワックスを厚さ $0.35 \mathrm{~mm}$ ，長さ 20 $\mathrm{mm}$, 愊 $10 \mathrm{~mm}$ の大きさにしたものを通法に従つて埋 没し，遠心鋳造した。 その後，本実験で行つた方法に従 つて, degassing, 陶材築盛, 焼成した. なお陶材の厚さ は, 築盛時, 約 $2.0 \mathrm{~mm}$, 焼付後, 約 $1.45 \mathrm{~mm}$ となつ た. 陶材烧成完了した試料の陶材を焼付けてない側の金 属面中央に, 歪ゲージを長さ方向 $(\mathrm{x})$ ，および幅方向 $(\mathrm{y})$ に 1 枚ずつ貼付した（図 6 ）. 金属表面および歪ゲージ には、ユーティリティワックスを薄く被覆し, 絶縁した. 歪ゲージ端子は, 歪測定器（共和無線社製，SM-4J）に 接続した．陶材の除去には，50\%フッ化水素酸溶液を使 用した．試料を溶液中に浸漬し，陶材の溶解除去による 試料の変形量を, 歪測定器で 1 分間隔で読みとつた. 陶 材の溶解量（表層からの距離） $\mathrm{z}$ は，別に同様の方法で 作製した試料を使つて，1 分間隔で測定した結果から推 定した.

2. 唇面蒾頸部辺縁形態別の変形抵抗性に関寸る有限 要素法による数値計算

本実験で採用した 3 種の辺縁形態のちがいが，製作過

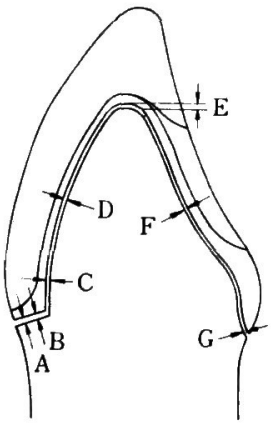

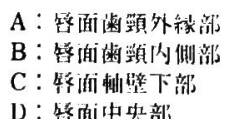

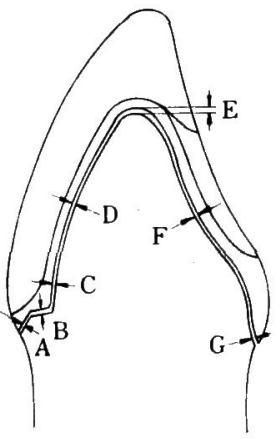

$E ：$ 切端部

$\mathrm{F}:$ 薄面中处被

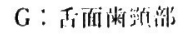

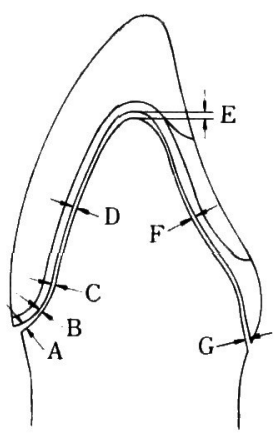


$68-68$

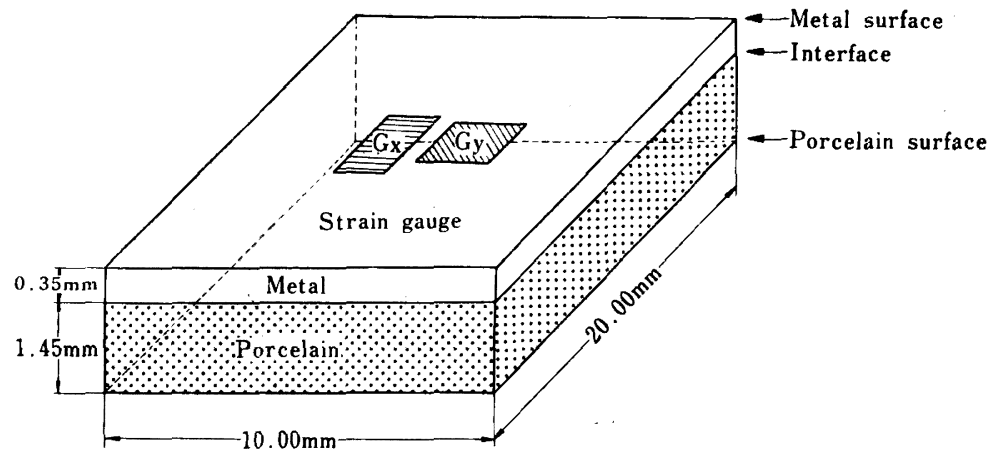

图 6 心力測定月の平板辩料

shoulder

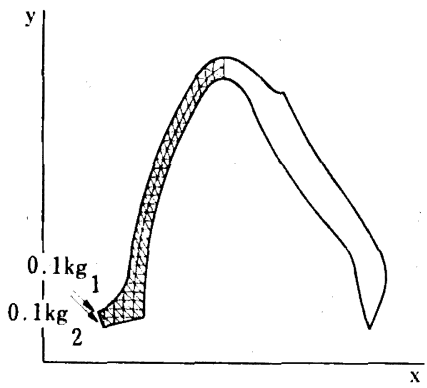

beveled shoulder

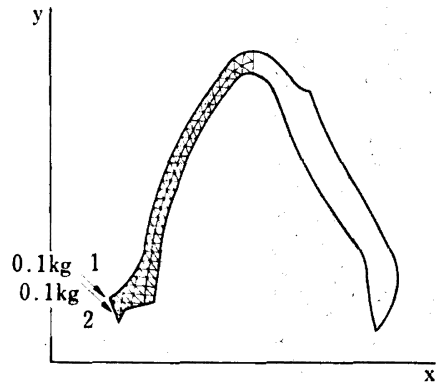

図 7 有限要秦法の分割モデル

chamfer

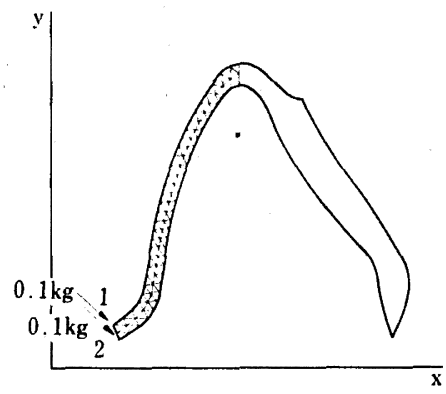

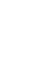

程で生じる種々の応力に対する唇側辺縁部の変形抵抗性 に及ぼす影響を知ることを目的とし，有限要素法を用い て弾性力学的に数值解析を試みた。

方法として，まず数值計算用要素分割モデルを作成し た. このモデルは, 本実験で使用した 3 種類の唇舌的矢 状断面の 20 倍拡大図である. 要素分割は, 主に冠の唇 側辺縁部一の応力の影響を考え唇側について行つた. そ の結果, shoulder type は要素 132, 節点 100 , beveled shoulder type は要素 134, 節点 101, chamfer type は要素 120 , 節点 93 となつた (図 7 ).

入力データーとして, それら各々の節点座標, 節点番 号, 要素番号のほかに要素の力学的特性, 拘束条件, 荷 重条件を決めた. すなわち, 力学的特性として材料定数 は, カタログ值および文献32)より金属のヤング率 $\mathrm{E}=$ $9,100 \mathrm{~kg} / \mathrm{mm}^{2}$, ポアソン比 0.33 とした. 拘束条件は, 切端部の 3 個の節点を $\mathrm{x}$ 方向, $\mathrm{y}$ 方向に固定した. 荷重 条件は, 粲顓部辺縁の節点 1,2 に $\mathrm{x}$ 軸, $\mathrm{y}$ 軸に $45^{\circ}$ の 鿇度で $0.1 \mathrm{~kg}$ ずつ計 $0.2 \mathrm{~kg}$ の負倚をかけた（図 7 ). なお，モデルは厚さ $1.0 \mathrm{~mm}$ の平板とし，解析は平面 応力問題とした. 計算には, 京都大学大型計算機センタ
- FACOM 230-60 型を使用し, 二次元的弹性解析プロ グラムを利用した.

\section{実験 結 果}

\section{I. 各操作過程における間隙量}

1. 鋳造後の試料について

亚造後の試料について, 唇舌的切断面に打ける $\mathrm{A}, \mathrm{B}$, $\mathrm{C}, \mathrm{D}, \mathrm{E}, \mathrm{F}, \mathrm{G}$ の各部位の間隙量は, 表 3 および図 8 に 示す通りである. 間隙量は, 各形態につき, 試料 6 個の 平均值および標準偏差で表した。なお，各部位での有意 差の検定は， $t$ 検定によつて $5 \%$ 危険率で判定した（表 $4)$.

部位Aでは, shoulder type の間陌量は, veneer type が $57.2 \mu$, full bake type が $58.7 \mu$ を示し, 最も間 隙量が大である. beveled shoulder type と chamfer type の間隙量法, 35.8 40.5 $\mu$ を示し, shoulder type との間に有意の差が認められた。部位 Bでは, chamfer type の間隙量が小さく, shoulder type との閶, およ び beveled shoulder type との間に有意の差が認めら 
表 3 鉞造後の間隙最

\begin{tabular}{|c|c|c|c|c|c|c|c|c|}
\hline 陶材被澓形態 & 政部辺綄形態 & A & $\mathrm{B}$ & $\mathrm{C}$ & D & $\mathrm{E}$ & $\mathrm{F}$ & $\mathrm{G}$ \\
\hline \multirow{3}{*}{ veneer type } & shoulder type & $\begin{array}{l}57.2 \\
(6.0)\end{array}$ & $\begin{array}{l}52.8 \\
(7.3)\end{array}$ & $\begin{array}{l}25.8 \\
(7.7)\end{array}$ & $\begin{array}{l}30.7 \\
(6.3)\end{array}$ & $\begin{array}{l}65.3 \\
(7.5)\end{array}$ & $\begin{array}{l}31.1 \\
(6.8)\end{array}$ & $\begin{array}{l}27.3 \\
(6.4)\end{array}$ \\
\hline & beveled shoulder type & $\begin{array}{l}40.5 \\
(8.9)\end{array}$ & $\begin{array}{c}47.7 \\
(10.7)\end{array}$ & $\begin{array}{l}28.7 \\
(8.0)\end{array}$ & $\begin{array}{l}29.3 \\
(2.5)\end{array}$ & $\begin{array}{l}58.2 \\
(5.2)\end{array}$ & $\begin{array}{l}33.5 \\
(4.3)\end{array}$ & $\begin{array}{l}26.7 \\
(5.3)\end{array}$ \\
\hline & chamfer type & $\begin{array}{l}35.8 \\
(6.2)\end{array}$ & $\begin{array}{l}38.3 \\
(7.2)\end{array}$ & $\begin{array}{l}32.0 \\
(9.9)\end{array}$ & $\begin{array}{l}29.8 \\
(8.6)\end{array}$ & $\begin{array}{l}57.3 \\
(5.5)\end{array}$ & $\begin{array}{l}41.5 \\
(5.8)\end{array}$ & $\begin{array}{l}37.7 \\
(4.9)\end{array}$ \\
\hline \multirow{3}{*}{ full bake type } & shoulder type & $\begin{array}{l}58.7 \\
(2.6)\end{array}$ & $\begin{array}{l}61.5 \\
(6.0)\end{array}$ & $\begin{array}{l}21.5 \\
(6.8)\end{array}$ & $\begin{array}{l}21.8 \\
(5.0)\end{array}$ & $\begin{array}{l}38.0 \\
(9.7)\end{array}$ & $\begin{array}{l}26.3 \\
(7.2)\end{array}$ & $\begin{array}{l}22.3 \\
\cdot(2.8)\end{array}$ \\
\hline & beveled shoulder type & $\begin{array}{l}37.3 \\
(3.5)\end{array}$ & $\begin{array}{c}54.5 \\
(11.0)\end{array}$ & $\begin{array}{l}24.5 \\
(3.3)\end{array}$ & $\begin{array}{l}21.0 \\
(3.9)\end{array}$ & $\begin{array}{l}24.5 \\
(3.3)\end{array}$ & $\begin{array}{l}27.3 \\
(7.5)\end{array}$ & $\begin{array}{l}22.5 \\
(6.1)\end{array}$ \\
\hline & chamfer type & $\begin{array}{l}38.2 \\
(6.3)\end{array}$ & $\begin{array}{l}29.5 \\
(4.4)\end{array}$ & $\begin{array}{l}27.5 \\
(5.3)\end{array}$ & $\begin{array}{l}21.3 \\
(7.1)\end{array}$ & $\begin{array}{l}32.7 \\
(3.8)\end{array}$ & $\begin{array}{l}26.3 \\
(4.9)\end{array}$ & $\begin{array}{l}14.5 \\
(3.5)\end{array}$ \\
\hline
\end{tabular}
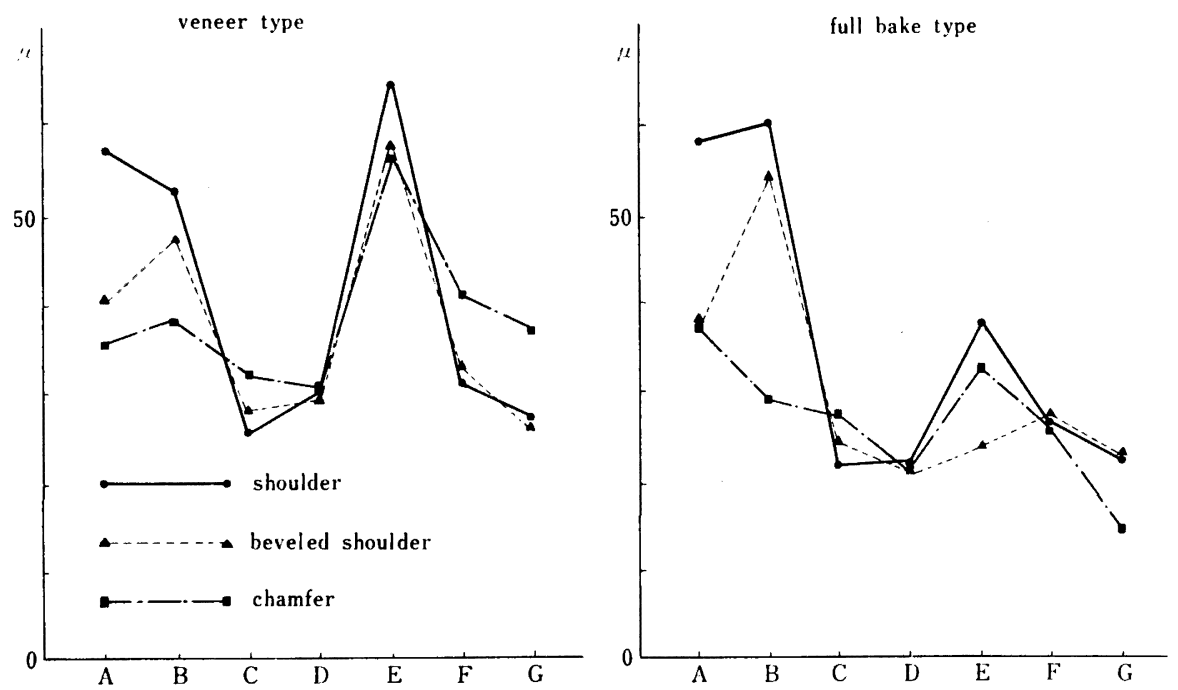

図 8 鏻造後の閒䏚些

れた. 部位 C, D, E, F, G では, 辺縁形態の差異によ る間隙量の差はほとんど認められなかつた。ただ，部 位Gにおいては chamfer type のみやや異なつた.こ れに対して, 陶材被覆形態別にみると, veneer type で

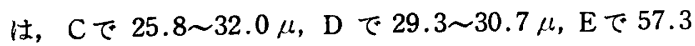

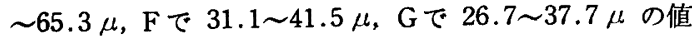
を示し, full bake type では, Cで 21.5〜27.5 $\mu, \mathrm{D}$

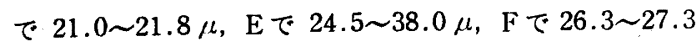
$\mu, \mathrm{G}$ で 14.5〜22.5 $\mu$ の值が示すように, veneer type に比べ, full bake type がかなり小さい值を示し, 部

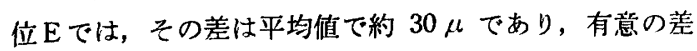

が認められた。

2. degassing 後の試料について

degassing 加熱操作後の試料の間隙量は, 表 5 と図 9 に示す通りである.

部位Aでは，間陌量は shoulder type が veneer ty. pe, full bake type ともに最も大であり, $56.3 \mu$ およ び $53.5 \mu$ の值を示し, beveled shoulder type との間, および full bake type の chamfer type との間に有意 差が認められた。部位 Bの間隙量は, veneer type で は, chamfer type, beveled shoulder type, shoulder type の順に $36.2 \mu, 38.2 \mu, 41.3 \mu$ を示し, ほとんど 
表 4 辺緑形態差おうよび陶材被朖形態差の $\mathrm{t}$ 検定

\begin{tabular}{|c|c|c|c|c|c|c|c|c|c|c|}
\hline & & \multicolumn{3}{|c|}{ Veneer } & \multicolumn{3}{|c|}{ Full bake } & \multicolumn{3}{|c|}{ Veneer-Full bake } \\
\hline & & $\mathrm{Sh}-\mathrm{Be}$ & $\mathrm{Be}-\mathrm{Ch}$ & $\mathrm{Ch}-\mathrm{Sh}$ & $\mathrm{Sh}-\mathrm{Be}$ & $\mathrm{Be}-\mathrm{Ch}$ & $\mathrm{Ch}-\mathrm{Sh}$ & Sh & $\mathrm{Be}$ & $\mathrm{Ch}$ \\
\hline \multirow{7}{*}{ as cast } & A & $3.811^{\circ}$ & 1.061 & $6.076^{\star}$ & 12. $023^{*}$ & 0.306 & 7. $368^{*}$ & 0.562 & 0.820 & 0.665 \\
\hline & $\mathrm{B}$ & 0.964 & 1.785 & $3.464^{\circ}$ & 1.368 & $5.169^{*}$ & $10.535^{*}$ & $2.255^{*}$ & 1.085 & $2.554^{*}$ \\
\hline & $\mathrm{C}$ & 0.640 & 0.635 & 1.211 & 0.972 & 1. 177 & 1.705 & 1.025 & 1. 189 & 0.986 \\
\hline & $\mathrm{D}$ & 0.506 & 0.136 & 0.207 & 0.309 & 0.091 & 0.141 & $2.710^{*}$ & 4. $389^{*}$ & 1.867 \\
\hline & $\mathrm{E}$ & 1.906 & 0.291 & 2. 107 & $3.227^{*}$ & $3.991^{*}$ & 1.246 & $9.454^{*}$ & $13.400^{*}$ & $9.014^{*}$ \\
\hline & $F$ & 0.731 & $2.714^{*}$ & $2.850^{*}$ & 0.236 & 0.273 & 0 & 1.187 & 1.757 & $4.904^{*}$ \\
\hline & $\mathrm{G}$ & 0.178 & $3.733^{\circ}$ & 3. $160^{\circ}$ & 0.073 & $2.786^{*}$ & 4. $263^{*}$ & 1.753 & 1.273 & $9.437^{*}$ \\
\hline \multirow{7}{*}{ degassed } & A & $5.449^{*}$ & $2.378^{*}$ & 1.968 & 2. $881^{*}$ & 0.092 & $3.791^{*}$ & 0.551 & 0.950 & $3.704^{*}$ \\
\hline & $B$ & 0.807 & 0.345 & 0.895 & $3.225^{\circ}$ & $2.349^{*}$ & $6.156^{*}$ & 2. $736^{*}$ & 0.357 & 1.855 \\
\hline & $\mathrm{C}$ & 0.997 & 1. 094 & 0.095 & 0.557 & 0.976 & 1.464 & $2.402^{*}$ & $2.067^{\circ}$ & $3.661^{*}$ \\
\hline & $\mathrm{D}$ & 0.789 & 1.384 & 0.645 & 0.287 & 0.241 & 0 & 1.335 & 0.888 & 1.551 \\
\hline & $\mathrm{E}$ & 0.629 & $4.427^{*}$ & $4.895^{\star}$ & 1. 856 & $2.879^{*}$ & 1. 692 & $2.645^{\circ}$ & 0.629 & 0.573 \\
\hline & $F$ & 0.323 & 1. 181 & $2.953^{\circ}$ & 0.674 & 0.769 & 0 & $3.504^{*}$ & 1.983 & $9.323^{*}$ \\
\hline & $\mathrm{G}$ & 1.006 & 0.764 & 1.865 & 0.472 & 1.447 & 1.120 & $2.514^{*}$ & 2.173 & 5. $632^{*}$ \\
\hline \multirow{7}{*}{$\begin{array}{c}\text { porcelain } \\
\text { fused }\end{array}$} & $A$ & $2.620^{*}$ & $4.374^{*}$ & 0.710 & $4.716^{*}$ & 4. $123^{*}$ & 1. 191 & 1.401 & 1.604 & 1. 182 \\
\hline & $\mathrm{B}$ & 1.886 & 1.906 & 3. $133^{*}$ & $2 . \overline{081}$ & 5. $629^{*}$ & $6.691^{\circ}$ & 1.245 & 0.342 & 3. $890^{*}$ \\
\hline & $\mathrm{C}$ & 0.708 & 0.686 & 0.070 & $2.700^{\circ}$ & $2.330^{*}$ & $4.848^{*}$ & 0.478 & $2.448^{\circ}$ & 4. $164^{*}$ \\
\hline & $\mathrm{D}$ & 0.879 & 0.293 & 0.270 & $2.558^{\circ}$ & 1.760 & 1.219 & 2. $650^{*}$ & $5.721^{*}$ & $2.745^{*}$ \\
\hline & $\mathrm{E}$ & 0.253 & 1. 144 & 1.217 & 0.029 & $3.303^{*}$ & $3.732^{*}$ & 1. 677 & 1.463 & 1.151 \\
\hline & $F$ & 0.080 & 1.348 & 4. $360^{\circ}$ & 0.375 & 0.472 & 0.047 & 1.671 & 1.987 & $3.445^{*}$ \\
\hline & $\mathrm{G}$ & 0.045 & 0.800 & 0.858 & 1.079 & 1.070 & 2.032 & 1.693 & $3.085^{*}$ & $2.901^{*}$ \\
\hline \multirow{7}{*}{ cemented } & A & $4.537^{*}$ & $5.096^{*}$ & 1. 765 & $7.303^{*}$ & $3.016^{*}$ & $5.645^{\circ}$ & 1.790 & 0.516 & 1.379 \\
\hline & $\mathrm{B}$ & 1.614 & 4. $112^{*}$ & $6.531^{\circ}$ & $5.178^{*}$ & 14. $140^{*}$ & $30.467^{*}$ & $2.930^{*}$ & 0.478 & $6.456^{\circ}$ \\
\hline & C & 1.775 & 1.952 & 0.303 & $2.829^{*}$ & 1.030 & $4.141^{*}$ & 1.034 & $2.071^{*}$ & $5.224^{*}$ \\
\hline & $\mathrm{D}$ & 0.494 & 0.403 & 0.656 & $3.967^{\circ}$ & 0.797 & 3. $949^{\circ}$ & 1.629 & $7.489^{*}$ & $3.477^{*}$ \\
\hline & $\mathrm{E}$ & 0.299 & 1.617 & 0.912 & 1.545 & $5.297^{\circ}$ & $6.435^{*}$ & 1.563 & 0.354 & 2.019 \\
\hline & $F$ & 0.115 & 0.642 & 0.518 & 1.771 & 1.442 & $2.349^{*}$ & 0.840 & $2.453^{*}$ & $4.727^{*}$ \\
\hline & G & 0.228 & 0.258 & 0.747 & 1.660 & 1.213 & 2. $623^{*}$ & 1.892 & 4. $046^{*}$ & $8.831^{\circ}$ \\
\hline
\end{tabular}

*危険率 $5 \%$ で有意差の認められるもの

差は認められない.これに対し, full bake type では, chamfer type, beveled shoulder type, shoulder type の順に $25.7 \mu, 36.5 \mu, 54.0 \mu$ の値を示し, 辺縁形態 による間隙量の差が veneer type に比べかなり認めら

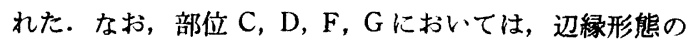
違いによる間隙量の差はほとんど認められなかつたが陶 材被覆形態の違いによる間隙量の差がかなり認められ た. すなわち, veneer type では, 部位Cで 26.2 31.5 $\mu, \mathrm{D}$ で 23.0〜28.2 $\mu, \mathrm{F} て ゙ 23.5 \sim 31.5 \mu, \mathrm{G}$ で 28.2 〜35.0 $\mu$ の值を示した. これに対し, full bake type では, Cで 15.0〜20.2

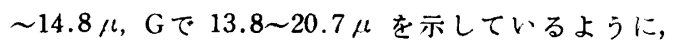

full bake type の方が veneer type よりも間吵量が小 さく, 両 type における差が大きく, C, F, G では両者 間に有意差を認めた。部位 Eでは, beveled shoulder <shoulder<chamfer の順に辺縁形態による間隙量の 差が認められ, beveled shoulder type と chamfer type の間に沬有意の差が楒められた。

3. 陶材焼付け後の試料について

opaque 陶材焼付けからはじまり, dentin, enamel 陶 材焼付け, glazing まで行い完成した試料について測定 した切断面における間隙量は表 6 と図 10 に示す通りで ある。

部位Aにおいては, 辺縁形態による差, 陶材被覆形態 
表 5 Degassing 後 $\sigma$ 間陌量

\begin{tabular}{|c|c|c|c|c|c|c|c|c|}
\hline 陶材被覆形態 & 米澒部辺緣形態 & A & B & $\mathrm{C}$ & $\mathrm{D}$ & $\mathrm{E}$ & $\mathrm{F}$ & G \\
\hline \multirow{3}{*}{ veneer type } & shoulder type & $\begin{array}{l}56.3 \\
(5.2)\end{array}$ & $\begin{array}{l}41.3 \\
(6.4)\end{array}$ & $\begin{array}{l}31.0 \\
(9.1)\end{array}$ & $\begin{array}{l}25.8 \\
(6.1)\end{array}$ & $\begin{array}{l}44.5 \\
(7.4)\end{array}$ & $\begin{array}{l}23.5 \\
(5.7)\end{array}$ & $\begin{array}{l}28.2 \\
(5.0)\end{array}$ \\
\hline & beveled shoulder type & $\begin{array}{c}39.3 \\
(5.6)\end{array}$ & $\begin{array}{l}38.2 \\
(6.9)\end{array}$ & $\begin{array}{l}26.2 \\
(7.5)\end{array}$ & $\begin{array}{l}23.0 \\
(6.2)\end{array}$ & $\begin{array}{l}41.7 \\
(8.0)\end{array}$ & $\begin{array}{c}25.3 \\
(12.4)\end{array}$ & $\begin{array}{l}31.8 \\
(7.1)\end{array}$ \\
\hline & chamfer type & $\begin{array}{l}48.7 \\
(7.9)\end{array}$ & $\begin{array}{c}36.2 \\
(12.4)\end{array}$ & $\begin{array}{l}31.5 \\
(9.2)\end{array}$ & $\begin{array}{l}28.2 \\
(6.8)\end{array}$ & $\begin{array}{l}62.3 \\
(6.5)\end{array}$ & $\begin{array}{l}31.5 \\
(3.4)\end{array}$ & $\begin{array}{l}35.0 \\
(7.4)\end{array}$ \\
\hline \multirow{3}{*}{ full bake type } & shoulder type & $\begin{array}{c}53.5 \\
(11.3)\end{array}$ & $\begin{array}{l}54.0 \\
(9.4)\end{array}$ & $\begin{array}{c}20.2 \\
(6.2)\end{array}$ & $\begin{array}{l}20.7 \\
(7.1)\end{array}$ & $\begin{array}{l}55.5 \\
(7.0)\end{array}$ & $\begin{array}{l}13.2 \\
(4.4)\end{array}$ & $\begin{array}{l}18.2 \\
(7.9)\end{array}$ \\
\hline & beveled shoulder type & $\begin{array}{c}34.2 \\
(11.9)\end{array}$ & $\begin{array}{l}36.5 \\
(9.4)\end{array}$ & $\begin{array}{l}18.3 \\
(5.6)\end{array}$ & $\begin{array}{l}19.5 \\
(7.4)\end{array}$ & $\begin{array}{c}45.3 \\
(11.5)\end{array}$ & $\begin{array}{l}14.8 \\
(3.8)\end{array}$ & $\begin{array}{c}20.7 \\
(10.3)\end{array}$ \\
\hline & chamfer type & $\begin{array}{c}33.7 \\
(6.0)\end{array}$ & $\begin{array}{l}25.7 \\
(6.2)\end{array}$ & $\begin{array}{l}15.0 \\
(6.1)\end{array}$ & $\begin{array}{l}20.7 \\
(9.7)\end{array}$ & $\begin{array}{c}65.7 \\
(13.0)\end{array}$ & $\begin{array}{l}13.2 \\
(3.4)\end{array}$ & $\begin{array}{l}13.8 \\
(5.5)\end{array}$ \\
\hline
\end{tabular}
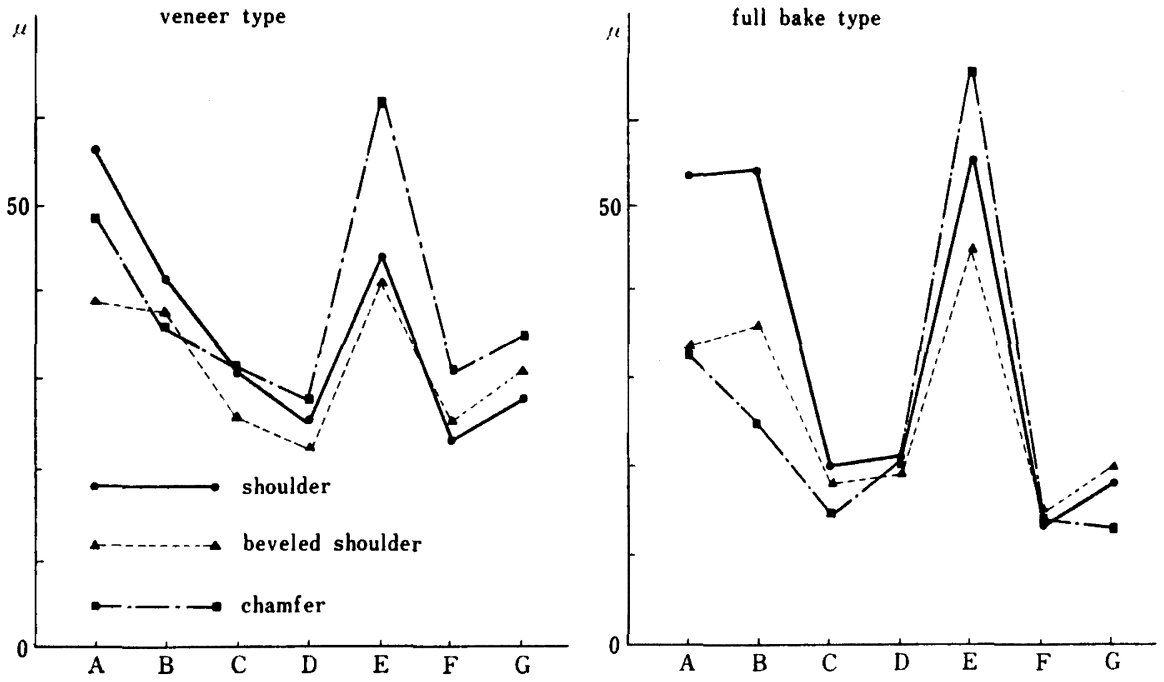

図 9 Degassing 後の間隙前

による差ともに認められた.すなわち，辺縁形態別にみ れば, veneer type では, chamfer type $71.3 \mu$, shou. lder type $66.7 \mu$, beveled shoulder type $50.3 \mu$ の 値を示した.これに対し, full bake type では, cham. fer type $64.5 \mu$, shoulder type $58.5 \mu$, beveled shoulder type $44.3 \mu$ の值が示す通り beveled shoulder type が他の 2 type に比へると間隙量が小さく, それ らの間には有意の差が認められた. 陶材被覆形態別にみ ると, veneer type に比へ, full bake type の方がや や小さい值を示した. 部位Bにおいても, full bake type の方が小さい値を示した。 なお, 部位 C, D, F, G では
辺縁形態よりも陶材被覆形態による差が大きく, veneer type では, 部位 $\mathrm{C}$ が $27.0 \sim 30.5 \mu$, Dで 34.5 37.7 $\mu, \mathrm{F}$ で 31.5〜 40.3 $\mu$, Gで 30.3〜35.0 $\mu$ の值を示し た。これに対して full bake typeにおいては，部位 C

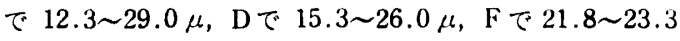
$\mu, \mathrm{G} て ゙$ 14.8〜25.8 $\mu$ の值を示し, やはり full bake

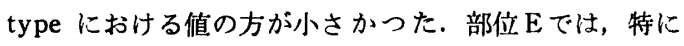
形態差は認められなかつた.

4. セメント合着後の試料について

i. 七メント合着後の間隙量

セメント合着後の間隙量の测定結果は, 表 7 と図 11 
表 6 陶材姺付後の間㗂洫

\begin{tabular}{|c|c|c|c|c|c|c|c|c|}
\hline 陶材被䛃非態 & 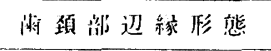 & A & B & $\mathrm{C}$ & $\mathrm{D}$ & $E$ & $\mathrm{~F}$ & G \\
\hline \multirow{3}{*}{ veneer type } & shoulder type & $\begin{array}{c}66.7 \\
(13.2)\end{array}$ & $\begin{array}{c}72.2 \\
(20.4)\end{array}$ & $\begin{array}{l}27.0 \\
(8.0)\end{array}$ & $\begin{array}{l}37.7 \\
(6.0)\end{array}$ & $\begin{array}{c}75.7 \\
(11.3)\end{array}$ & $\begin{array}{c}31.5 \\
(11.6)\end{array}$ & $\begin{array}{l}34.8 \\
(6.1)\end{array}$ \\
\hline & bereled shoulder type & $\begin{array}{l}50.3 \\
(7.8)\end{array}$ & $\begin{array}{c}54.5 \\
(10.6)\end{array}$ & $\begin{array}{l}30.5 \\
(9.1)\end{array}$ & $\begin{array}{l}34.5 \\
(6.6)\end{array}$ & $\begin{array}{l}74.2 \\
(8.1)\end{array}$ & $\begin{array}{c}32.0 \\
(10.1)\end{array}$ & $\begin{array}{l}35.0 \\
(8.9) \\
\end{array}$ \\
\hline & chamfer type & $\begin{array}{l}71.3 \\
(8.8)\end{array}$ & $\begin{array}{l}44.7 \\
(6.8)\end{array}$ & $\begin{array}{l}27.3 \\
(6.9)\end{array}$ & $\begin{array}{c}36.2 \\
(12.6)\end{array}$ & $\begin{array}{l}68.3 \\
(9.7)\end{array}$ & $\begin{array}{c}40.3 \\
(11.2)\end{array}$ & $\begin{array}{c}30.3 \\
(11.3)\end{array}$ \\
\hline \multirow{3}{*}{ full bake type } & shoulder type & $\begin{array}{l}58.5 \\
(5.6)\end{array}$ & $\begin{array}{l}61.0 \\
(8.3)\end{array}$ & $\begin{array}{l}29.0 \\
(6.4)\end{array}$ & $\begin{array}{l}26.0 \\
(9.0)\end{array}$ & $\begin{array}{c}65.0 \\
(10.8)\end{array}$ & $\begin{array}{l}22.0 \\
(7.7)\end{array}$ & $\begin{array}{c}25.8 \\
(11.5)\end{array}$ \\
\hline & beveled shoulder type & $\begin{array}{l}44.3 \\
(4.8)\end{array}$ & $\begin{array}{l}52.8 \\
(6.0)\end{array}$ & $\begin{array}{l}19.7 \\
(5.5)\end{array}$ & $\begin{array}{l}15.3 \\
(4.9)\end{array}$ & $\begin{array}{c}65.2 \\
(12.7)\end{array}$ & $\begin{array}{l}23.3 \\
(3.6)\end{array}$ & $\begin{array}{l}19.5 \\
(8.5)\end{array}$ \\
\hline & chamfer type & $\begin{array}{c}64.5 \\
(11.0)\end{array}$ & $\begin{array}{c}25.5 \\
(10.0)\end{array}$ & $\begin{array}{l}12.3 \\
(5.5)\end{array}$ & $\begin{array}{l}20.7 \\
(5.7)\end{array}$ & $\begin{array}{c}75.3 \\
(11.3)\end{array}$ & $\begin{array}{l}21.8 \\
(6.9)\end{array}$ & $\begin{array}{l}14.8 \\
(6.6)\end{array}$ \\
\hline
\end{tabular}
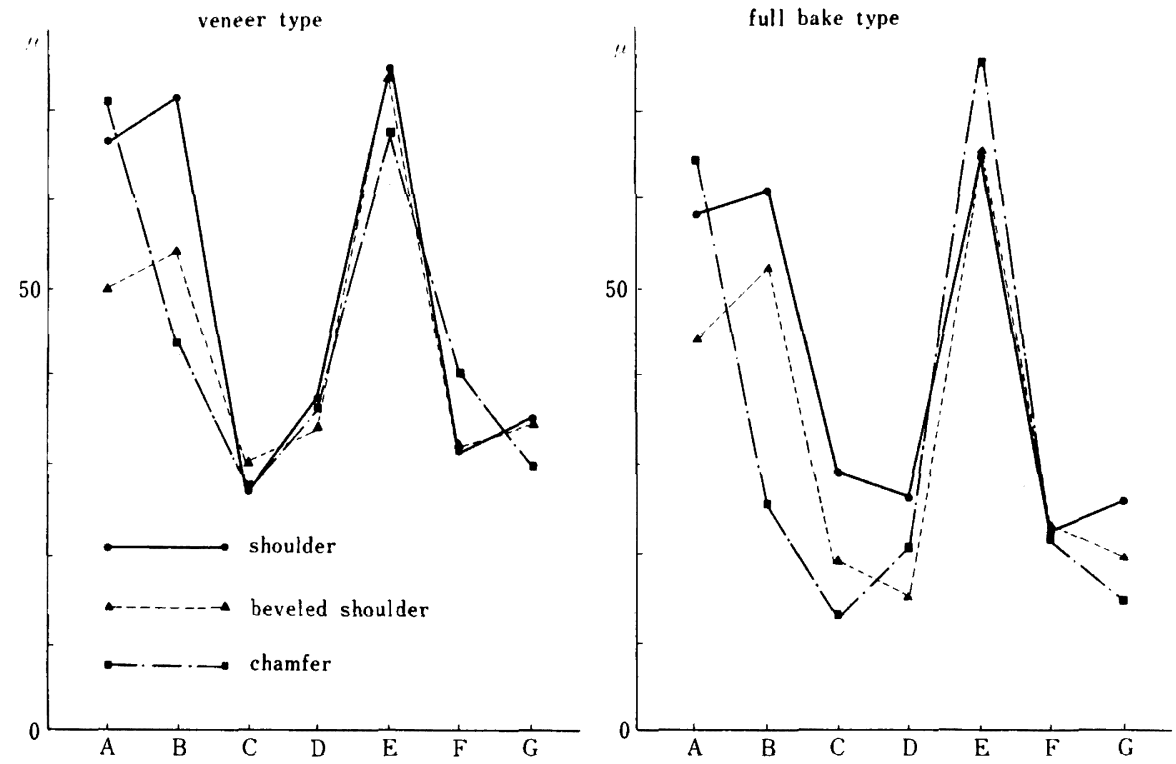

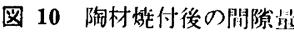

に示す通りである。

部位Aでは, shoulder type がセメント層は最も厚 $く$, veneer type で $104.3 \mu$, full bake type で 120.5 $\mu$ の值を示した. 一方, beveled shoulder type がセ メント層は最も薄く, veneer type で $71.5 \mu$, full bake type で $73.3 \mu$ の值を示した。部位Eでは, chamfer type がセメント畨は最も薄く, veneer type $96.5 \mu$, full bake type で $86.8 \mu$ の值を示した. また，他の 部位, C, D, F, G では veneer type で約 $40 \sim 50 \mu$, full bake type で約 $20 \sim 40 \mu$ の值を示した. このこと は, 切断面における側壁部では, veneer type に比べ full bake type の方が，セメント痛の厚さは概して小 さいことがわかつた.

ii. セメント合着による浮き上がり

セメント合着後の試料の切端部におけるセメント層の 厚さから，陶材烓付後の試料の間隙量を差し引いた值を もつて，セメント合着による浮き上がり值とした（表 8 ， 図 12).この浮き上がり量は, veneer type では shoulder type が $31.5 \mu$, beveled shoulder type が 37.0 $\mu$, chamfer type が $28.2 \mu$ の值を示すように, 辺縁 形態による差がほとんど認められなかつた。 これに対 し, full bake type では, shoulder type が $61.5 \mu$, 


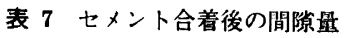

\begin{tabular}{|c|c|c|c|c|c|c|c|c|}
\hline 陶材被覆形態 & 畨頚沾辺緣形態 & A & B & $\mathrm{C}$ & $\mathrm{D}$ & $\mathrm{E}$ & $\mathrm{F}$ & G \\
\hline \multirow{3}{*}{ veneer type } & 'shoulder type & $\begin{array}{l}104.3 \\
(17.1)\end{array}$ & $\begin{array}{l}109.7 \\
(12.7)\end{array}$ & $\begin{array}{c}38.3 \\
(10.1)\end{array}$ & $\begin{array}{c}46.5 \\
(11.9)\end{array}$ & $\begin{array}{l}107.2 \\
(26.5)\end{array}$ & $\begin{array}{c}43.7 \\
(13.1) \\
\end{array}$ & $\begin{array}{l}41.3 \\
(7.0) \\
\end{array}$ \\
\hline & beveled shoulder type & $\begin{array}{l}71.5 \\
(4.6)\end{array}$ & $\begin{array}{c}96.5 \\
(15.5)\end{array}$ & $\begin{array}{l}28.2 \\
(9.6)\end{array}$ & $\begin{array}{l}44.0 \\
(3.5)\end{array}$ & $\begin{array}{l}111.2 \\
(19.3)\end{array}$ & $\begin{array}{c}42.8 \\
(13.4)\end{array}$ & $\begin{array}{c}42.5 \\
(10.8)\end{array}$ \\
\hline & chamfer type & $\begin{array}{l}90.7 \\
(8.0)\end{array}$ & $\begin{array}{c}64.2 \\
(11.4)\end{array}$ & $\begin{array}{c}40.2 \\
(11.6)\end{array}$ & $\begin{array}{c}41.8 \\
(12.9)\end{array}$ & $\begin{array}{c}96.5 \\
(11.1)\end{array}$ & $\begin{array}{c}47.2 \\
(10.1)\end{array}$ & $\begin{array}{l}43.7 \\
(3.6)\end{array}$ \\
\hline \multirow{3}{*}{ full bake type } & shoulder type & $\begin{array}{l}120.5 \\
(14.1)\end{array}$ & $\begin{array}{r}126.5 \\
(6.0)\end{array}$ & $\begin{array}{c}32.3 \\
(10.0) \\
\end{array}$ & $\begin{array}{l}37.0 \\
(7.9) \\
\end{array}$ & $\begin{array}{l}126.5 \\
(14.6)\end{array}$ & $\begin{array}{c}37.7 \\
(11.6) \\
\end{array}$ & $\begin{array}{c}30.3 \\
(12.4) \\
\end{array}$ \\
\hline & beveled shoulder type & $\begin{array}{l}73.3 \\
(7.2)\end{array}$ & $\begin{array}{l}100.2 \\
(10.9)\end{array}$ & $\begin{array}{l}18.0 \\
(7.3)\end{array}$ & $\begin{array}{l}19.8 \\
(7.1)\end{array}$ & $\begin{array}{l}114.5 \\
(12.2)\end{array}$ & $\begin{array}{l}29.0 \\
(3.2)\end{array}$ & $\begin{array}{l}20.3 \\
(8.0)\end{array}$ \\
\hline & chamfer type & $\begin{array}{l}85.0 \\
(6.2)\end{array}$ & $\begin{array}{l}31.7 \\
(4.7)\end{array}$ & $\begin{array}{l}14.7 \\
(2.9)\end{array}$ & $\begin{array}{l}22.5 \\
(4.3)\end{array}$ & $\begin{array}{l}86.8 \\
(3.9)\end{array}$ & $\begin{array}{l}25.7 \\
(4.7)\end{array}$ & $\begin{array}{l}15.0 \\
(7.1)\end{array}$ \\
\hline
\end{tabular}
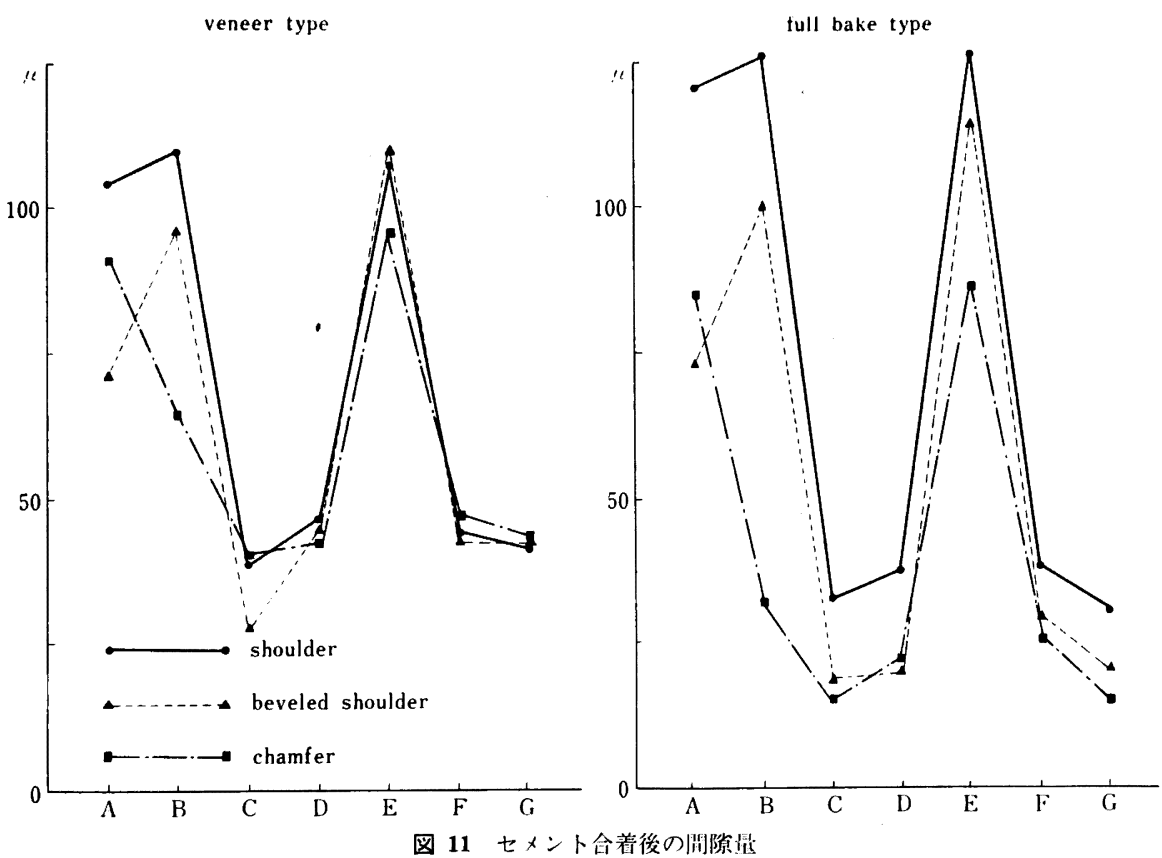

表 8 セメント合着による浮き上がり聂 (切端部)

\begin{tabular}{c|c|c|c}
\hline $\begin{array}{c}\text { 辺縁形態 } \\
\text { 被覆形隹 }\end{array}$ & shoulder & $\begin{array}{c}\text { beveled } \\
\text { shoulder }\end{array}$ & chamfer \\
\hline veneer & 31.5 & 37.0 & 28.2 \\
\hline full bake & 61.5 & 49.3 & 11.5 \\
\hline
\end{tabular}

beveled shoulder type $11.5 \mu$ の浮き上がり值を示し, 辺縁形態による差が chamfer type と他 2 者との閒にみられた.

\section{II. 測定部位別の間隙量}

以上の測定結果について, 測定部位別に辺縁形態差, 陶材被覆形態差を $\mathrm{t}$ 検定により検討した結果，唇面歯頸 部A，Bでは辺縁形態差および陶材被覆形態茎が認めら れた.

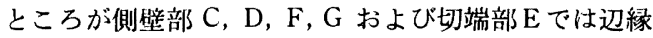
形態差はほとんどなく，主に陶材被覆形態差が認められ た. 唇面歯頸部 A ，Bについては辺縁形態別および陶材 
被覆形態別に，側壁部 C, D, F, G および切端部 Eにつ いては陶材被覆形態別に 3 種類の蒋領部辺縁形態の平均 值で表わし，测定部位別に各操作過程を通じての変化を 検討した（図 13-1，13-2，14）.

1. 唇面歯形部について

i. 部位 A (唇面歯頸外縁部) について

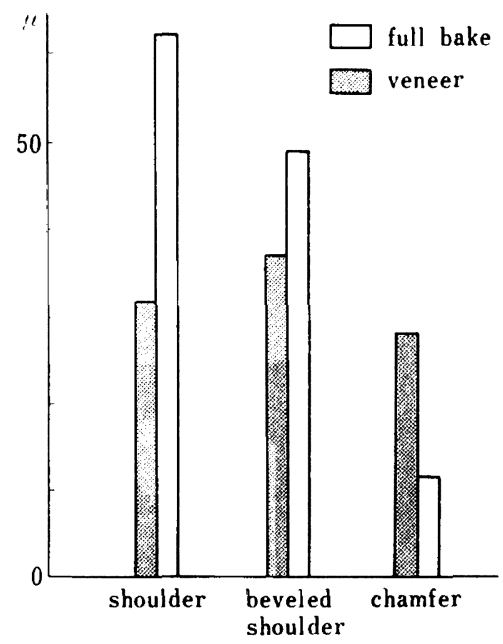

図 12 セメント合着に上る浮き上がり星（切 端部)

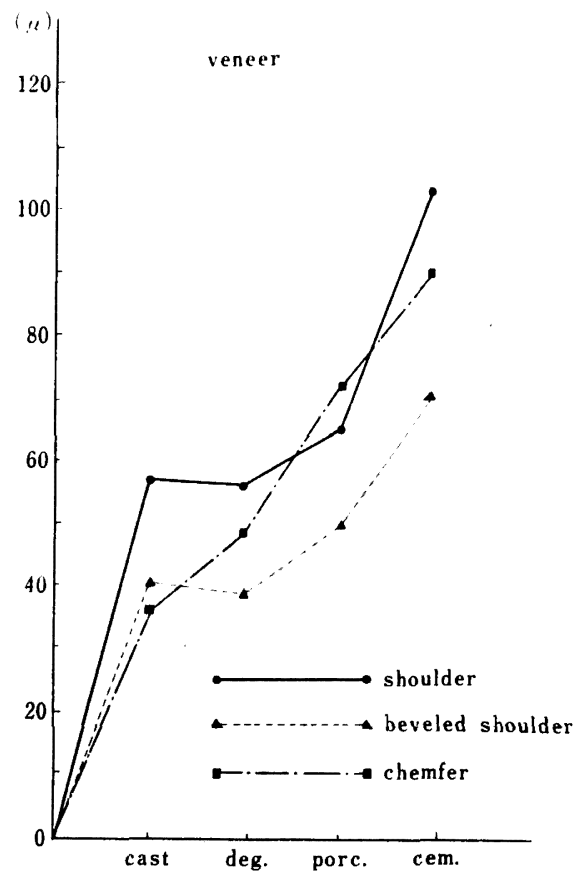

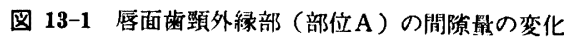

セメント合着後までの間隙量の変化のうち，まず鋳造 後において間隙量が大きく認められた. その後, shou Ider type, beveled shoulder type は同様の傾向を示 し，陶材焼付後まで大きい変化はない，一方， chamfer type における陶材焼付けによる間隙量の変化は, shoulder type や beveled shoulder type に比べ大きい増 大が認められた。最終的なセメント合着による浮き上が りは shoulder type が最も大きく, セメント層の大き さは, shoulder $>$ chamfer $>$ beveled shoulder の順と なつた（図 13-1）.

ii. 部位 B（唇面歯頸内側部）について

鋳造後の間隙量はかなり大きく, shoulder type, beveled shoulder type 4 degassing でやや減少し, 陶 材焼付け後再び増大した．そしてセメント合着で大きく 増大が認められた. 一方, chamfer type においては間 陌量およびその変化が小さかつた（図 13-2）.

2. 切端部および側壁部について

i. 部位 E (切端部)について

錆造後の間隙量は veneer type と full bake type とで大きく異なり, つづいて degassing 後の間隙量は veneer type で減少 full bake type では増大し両者はほ ぼ同等となり，陶材焼付け後およびセメント合着後にお いて, 雨者の間隙量は同様に増大が認められた（図 14）.

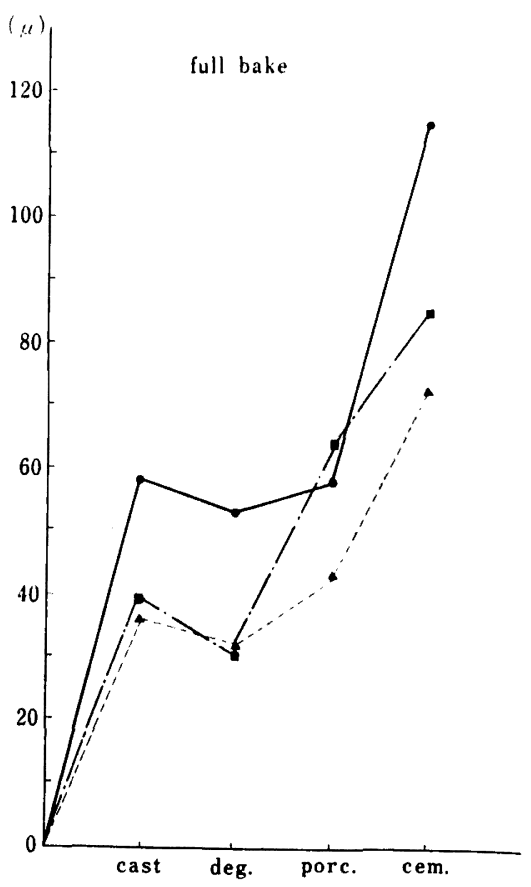



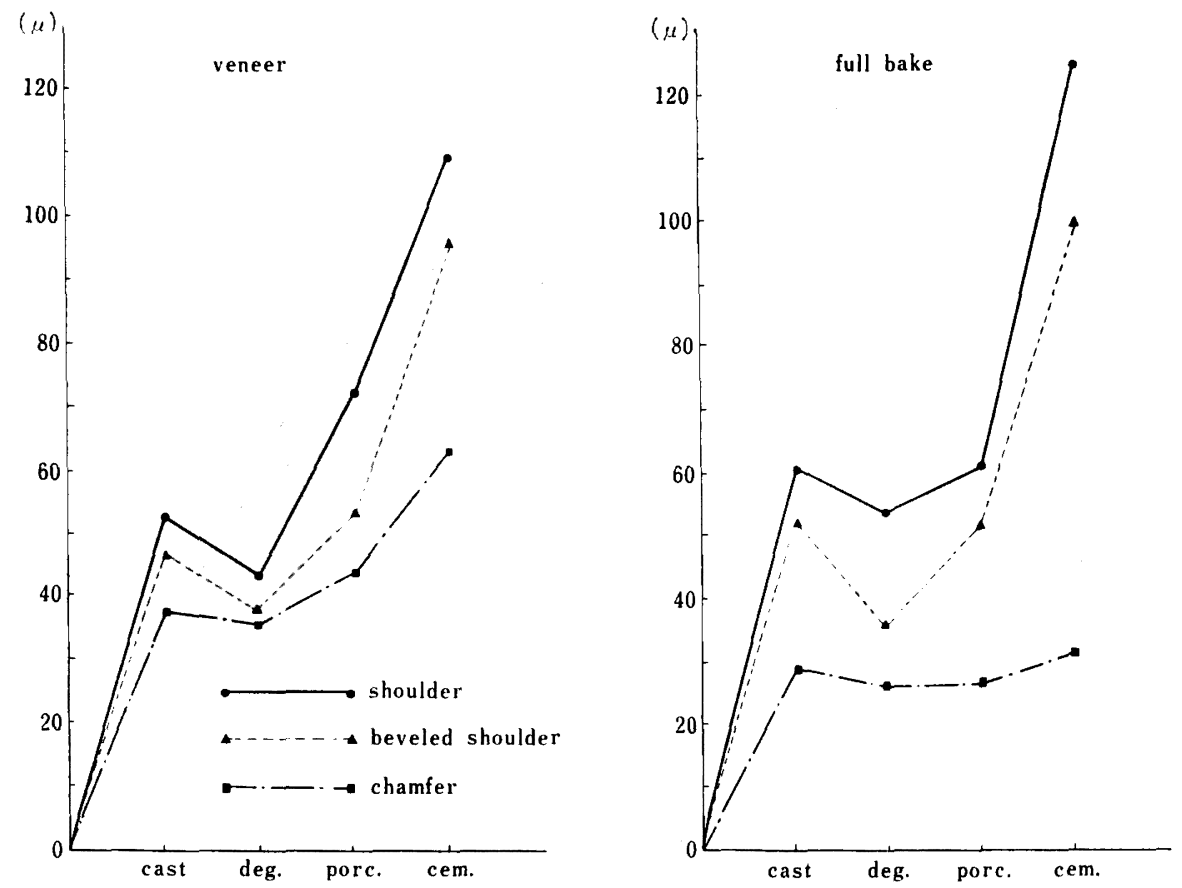

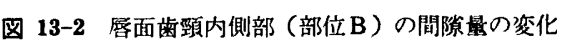
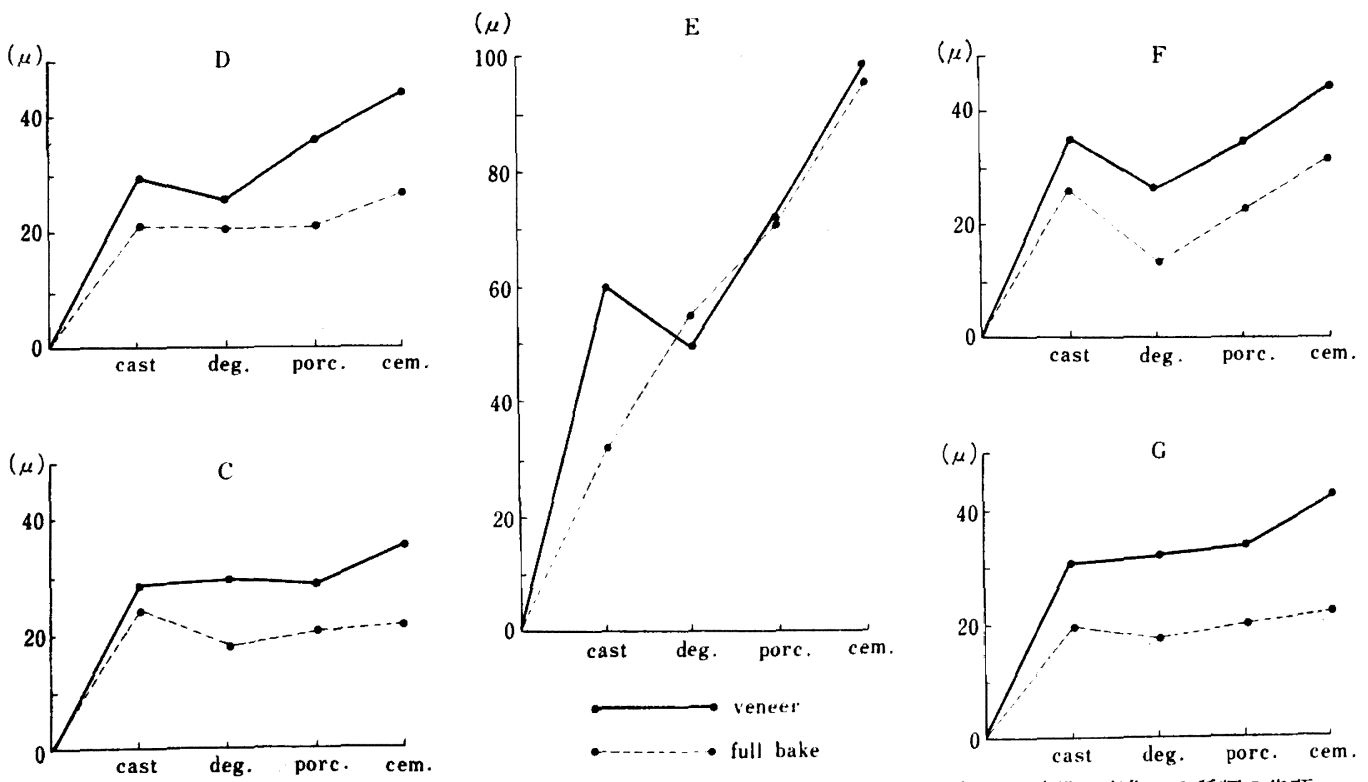

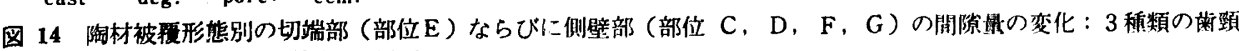
部辺縁形態の平均值を表示した. 

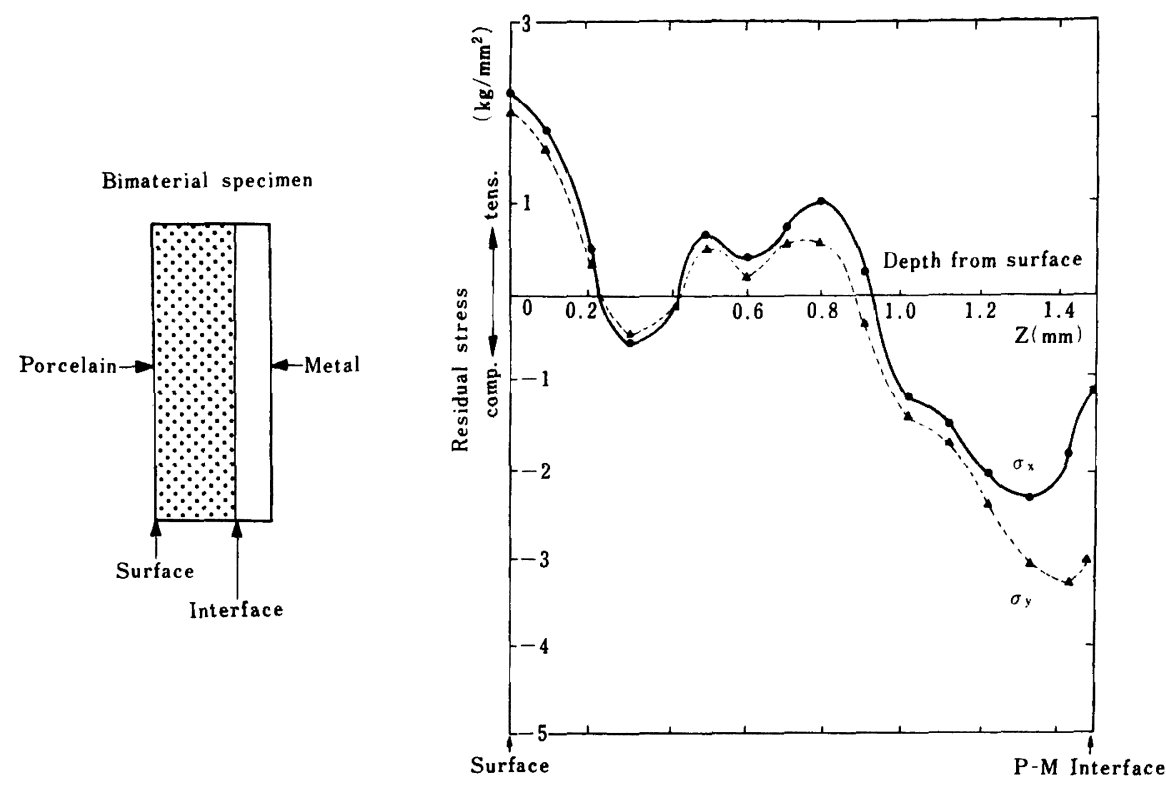

図 15 陶材中の残留応力

ii. 部位 $\mathrm{C}, \mathrm{D}, \mathrm{F}, \mathrm{G}$ (側壁部) について

鋳造後, veneer type では 30〜35 $\mu$ を示し, full bake type では 20〜25 $\mu$ を示し, D, F, G では有意 差を認めた. その後のすべての操作過程を通じて, veneer type に比べ full bake type の方が間隙量が小さ く, 有意差が認められた. 最終的なセメント合着後のセ メント層は veneer type で 35〜45 $\mu$, full bake type で 20〜30 $\mu$ であつた（図 14）.

III. 陶材焼成により発生する応力値および辰面菌頸 部辺縁形態別の変形抵抗性

1. 陶材焼成により発生する応力值

雨ゲージから得た值によつて応力值を算出するため に，堤44)らが鋳造体の残留応力分布の測定に用いた式を 使用した.すなわち，金属と陶材の合計の厚さを $\mathrm{h}$, 陶 材の溶解量を $\mathrm{z}, \mathrm{x}, \mathrm{y}$ 方向の歪量を $\varepsilon_{\mathrm{x}}, \varepsilon_{\mathrm{y}}$ とし, ポア ソン比を $\nu$, 平板内に残留している主応力を $\sigma_{\mathrm{x}}, \sigma_{\mathrm{y}}$ と する. 裏面での $\mathrm{x}, \mathrm{y}$ 方向の歪量 $\varepsilon_{\mathrm{x}}, \varepsilon_{\mathrm{y}}$ を表層からの 除去量 $\mathrm{z}$ の関数として計測することにより,

$$
\begin{aligned}
\mathrm{U}_{\mathrm{x}}= & -\frac{\mathrm{E}}{2}\left[(\mathrm{~h}-\mathrm{z}) \frac{\mathrm{d} \varepsilon_{\mathrm{x}}}{\mathrm{d} z}-4 \varepsilon_{\mathrm{x}}\right. \\
& \left.+6(\mathrm{~h}-\mathrm{z}) \int_{0}^{z} \frac{\varepsilon_{\mathrm{x}}}{(\mathrm{h}-\xi)^{2}} \mathrm{~d} \xi\right] \\
\mathrm{U}_{\mathrm{y}}= & -\frac{\mathrm{E}}{2}\left[(\mathrm{~h}-\mathrm{z}) \frac{\mathrm{d} \varepsilon^{\mathrm{y}}}{\mathrm{d} z}-4 \varepsilon^{\mathrm{y}}\right.
\end{aligned}
$$

$$
\begin{aligned}
& \left.+6(\mathrm{~h}-z) \int_{0}^{z} \frac{\varepsilon_{y}}{(\mathrm{~h}-\xi)^{2}} \mathrm{~d} \xi\right] \\
\sigma_{x}= & \frac{1}{1-\nu^{2}}\left(\mathrm{U}_{\mathrm{x}}+\nu \mathrm{U}_{\mathrm{y}}\right) \\
\sigma_{\mathrm{y}}= & \frac{1}{1-\nu^{2}}\left(\mathrm{U}_{\mathrm{y}}+\nu \mathrm{U}_{\mathrm{x}}\right)
\end{aligned}
$$

の式から $\sigma_{\mathrm{x}}, \sigma_{\mathrm{y}}$ を求めることができる. その結果, 陶材内部の残留応力分布は図 15 に示す通りであつた. 以上の結果より, 陶材表層部には, 約 $2 \mathrm{~kg} / \mathrm{mm}^{2}$ の引張 り残留応力が存在するが, 陶材深部人行くにつれて, 引 張りから圧縮応力に変わり，金属と陶材の接合部付近の 陶材内には, 1〜3 kg/mm² の圧縮残留応力が存在してい ることがわかつた.

2. 有限要素法による唇面歯頚部辺縁形態別の変形抵 抗性

shoulder type, beveled shoulder type, chamfer type の各形態の唇側辺縁部の節点 1 および 2 の方向, y方向の変位, $\delta_{x}, \delta_{y}$ は表 9 のように求められた. 変 位量の絶対值 $\delta$ は $\left(\delta_{x}^{2}+\delta_{y}^{2}\right)^{1 / 2}$ として計算でき, 歯頸部 の 2 節点の平均值を求めた（表 9 ）. それによると, 形 態別の変位量は,

$\begin{array}{lcc} & \text { (20倍拡大模型) } & \text { (実物大) } \\ \text { shoulder } & 2.26 & 0.113 \\ \text { beveled shoulder } & 2.20 & 0.110 \\ \text { chamfer } & 2.29 & 0.115 \\ & & (\mathrm{~mm})\end{array}$




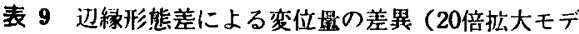
ルについて)

\begin{tabular}{|c|c|c|c|c|c|}
\hline & 節点果开 & $\delta x$ & $\delta y$ & $\delta$ & 平均储 \\
\hline \multirow{2}{*}{ shoulder } & 1 & 2.072 & -1.005 & 2.303 & \multirow{2}{*}{2.256} \\
\hline & 2 & 1.966 & -1.005 & 2.208 & \\
\hline \multirow{2}{*}{$\begin{array}{l}\text { beveled } \\
\text { shoulder }\end{array}$} & 1 & 2.050 & -0.957 & 2.263 & \multirow{2}{*}{2.202} \\
\hline & 2 & 1.894 & -0.998 & 2.141 & \\
\hline \multirow{2}{*}{ chamfer } & 1 & 2.097 & -0.982 & 2.315 & \multirow{2}{*}{2.290} \\
\hline & 2 & 2.000 & -1.066 & 2.266 & \\
\hline
\end{tabular}

となり, beveled shoulder < shoulder < chamfer の順に 大きく, beveled shoulder type に比へると, chamfer type は 1.05 倍変位量が大きい，換言すれば，変形抵抗 性は, chamfer type に比べると beveled shoulder type の方が大きいことが明らかとなつた.この解析結果は, 陶材焼付けによる唇面歯䫫外縁部（部位A）に生じる間 隙量の増大が, chamfer type において著明であつた結 果と類似している.

\section{考察}

支台歯に対し良好に適合するということは，歯冠補綴 物の具備すべき最む重要な条件の一つであり，その良否 が補緅物の価値を左右すると言つても過言ではない。

金属焼付ポーセレン冠は，審美的かつ強度的要求に応 えたものとして歯科補緅臨床に紹介されるや否や急速に 普及し，現在では，前菊部における代表的歯冠補緅物と して用いられている.ところがこの補緅物に関して，臨 床家の間から金属体の試適時適合が良好であつても，陶 材焼付け完成後菌頸部の適合が不良 ${ }^{6,24,25,33)}$ になるとい うことや，歯肉の変色や炎症や退縮などの問題点が指摘 されている.

ちなみに予後調査結果 ${ }^{2)}$ によれば，唇面蕋頸外縁部の 適合状態がスムーズなものは $20.5 \%$ にすぎず，その他 のものは近心, 中央, 遠心のいずれかの部位でステップ を有していた．また，長軸方向の間隙も，探針で感知で きないものは $27.4 \%$ にすぎず，他のものはすべて不均 一な間隙を有していることがわかつた.このように，日 常の臨木において，良好な適合状態を得ることは，容易 ではないように思われる。

歯頸部に扔ける冠不適合の原因は，まず基喏的問題と して, 印象材, 模型材, ワックスの変形や面あらさ ${ }^{26)}$, 鋳造操作中の変形，あるいはセメントによる浮き上がり
のほかに，金属焼付ポーセレン冠に特異的な高温での熱 処理および陶材焼成にともなう応力による冠の変形 ${ }^{24}$, 25,31,35)が考えられる.つぎに臨床的問題として，一連の 操作過程の中でも, その出発点であり, 術者に依存度の 大きい支台歯形成が重要な因子と考えられる.すなわ ち，より良好な適合と冠辺縁部におけるセメント層の縮 少を計るためには，支台歯形成についてその形態抢よび 形成法を再考する必要がある. なかでも歯頸部辺縁形態 は，冠辺緑部の適合と密接に関係するため特に重要であ るが，理論的裏付けのないままに，陶材築盛の便宜上， shoulder type の形成法7,36,37) が行なわれてきた. とこ ろが shoulder type では冠の浮き上がりの影響が冠辺 縁部に大きく現われやすいため，それに対する改善策と して, 鋳造修復物における歯頸部辺縁形態と適合性の考 え方を取り入れて beveled shoulder type や chamfer type が考えられるようになってきた。 これらのうち， beveled shoulder type の形成は, Brecker ${ }^{8}$ ), Shelby 34), Silver ${ }^{33)}$, 橋本 ${ }^{38)}$ らによつて晿えられているが，歯 頸部辺縁形態の差異と適合性に関しての検討は未だ十分 に試みられていない。

一方, 支台歯形態以外の重要な問題として, 陶材の被 覆形態がある．従来より主に陶材を唇面のみに焼付けた veneer type の方法がとられてきた.ところが，陶材破 折の予防および審美的要求から，金属と陶材の接合部を できるだけ舌側歯頸部人設定する方法も採用されてお り, veneer type に対して, 陶材をほぼ全面に焼付ける ため, full bake type と言われている. 佐藤 ${ }^{10)}$ は前歯 部金属焼付ポーセレン冠について，陶材被覆度のちが、 が破折強度に及ぼす影響について実験を行つている。こ の報告によれば，全部被覆型が安定した強度を有してい ることが明らかとなつている．しかし，陶材被覆形態の 差が冠の変形あるい牥適合性に及ぼす影響が予測される にもかかわらず，この点に関する基磷的研究が行われて いない。

そこで著者は, 鋳造後, degassing 後, 陶材焼付け後 およびセメント合着後の各操作過程における冠と支台歯 間の間隍量を測定することによつて，適合性の変化を把 握しようとした，すなわち，現在多く用いられている shoulder type おょび veneer type に対して辺縁形態 では chamfer type, beveled shoulder typeを, 陶材 被䠥形態では full bake type の各形態を取り入れ, 比 較検砷した。 さらに，陶材焼成により発生する応力を測 定するとともに有限要素法による数值計算により, 唇面 歯頸部辺縁形態別の変形抵抗性を検討した. 


\section{I. 試料および方法について}

金属焼付ポーセレン冠に関するここ数年間の研究はめ ざましく, 材料, 技術の進歩により, 焼付強度や寸法精 度もかなり向上はして来た. しかし, 基喽的研究が徐々 に臨床的条件へ接近して来たとはいえ，未だ棒状あるい

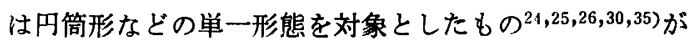
多く,それをもつて日常臨床における金属烧付ポーセレ ン冠の問題を検討するにはなお不充分である.また, 研 究課題が分化しすぎたために, 基礎実験結果と臨床応用 との間に未だ距離感があるように思われる.ことに金属 焼付ポーセレン冠の形態は複雑であり, 適合性に関して も，各部すべての間隙量とその製作過程における変化の 程度が異なることが予想されるため, 基礎実験結果から は值ちに臨床における冠の場合の適合状態を推定するこ とはできない。

本研究の主目的は, 形態的な面から支台歯に対する冠 の適合性を検討することである，従つて本実験では歯顠 部辺縁形態, 陶材被覆形態ともに, 臨床における金属焼 付ポーセレン冠の条件を具備した試料を用いた。

冠の適合度を知るには，もとの支台歯に戻して冠外面 から辺縁の浮き上がりや間隙量を測定する方法と, もと の支台歯に戻したものを切断し外面および内面の間隙量 を測定する方法がある。

前者の方法は, 全部鋳造冠の適合度を測定するにあた つてょく用いられていた. すなわち, shoulder type の 鋳造冠模型を使用して, shoulder 部における冠と支台 歯の間隙量を測定して適合度の判定を行つていた ${ }^{39,40)}$.

しかし，この方法では，鋳造冠を支台菌に試適した場合， 浮き上がりを生じても, 間隙として測定することがむず かしく, 特に鉡造冠の歯頸部辺縁が鋸歯状を呈すること があり，他の辺縁形態，たとえば， beveled shoulder type, chamfer type の鋳造冠の適合度を測定するこ とが困難であると思われる.

後者の方法の場合, 辺縁部はもちろんのこと, 内面の 状態が観察可能であり，より立体的な見方ができるとい うこと, 寸なわち冠の浮き上がりあるいは冠の変形など も間隙量を計測することによつて推察できる利点を有し ている. しかし，この方法では，同一の試料を経時的に 観察することができない短所がある. 本実験では，より 立体的な見方をするため後者の方法を用いた. 臨床形態 は複雑であり，厳密には各部すべて間隙量およびその変 化の程度も異ることが予想されるため, 冠全体の間隙量 とその変化を把握することは不可能に近いと思われる.

しかし，一断面の状態を観察することによつて，臨床的
問題の解明にあたつての一つの指標とすることは可能で あり, 特に正中断面は, 蒾頸部辺縁形態および陶材被覆 形態の差異による辺縁部の適合度の比較検討を行うため にも，最も代表的な観察面であると考えられる.

金属焼付ポーセレン冠は，審美性を有することを大き な特徴としている.そのため，冠の唇側辺縁部は歯肉縁 下に入れ，かつ冠の辺縁末端まで陶材が焼付いているこ とが必要である，そこで，陶材の入るスペースを確保し なければならないが，これらを満足する辺縁形態は自ず と限られてくる，つまり，従来から採用されてきた sh. oulder type のほかに, beveld shoulder type, cham. fer type の3形態が主に考えられるため，本実験ではそ れら 3 種類の形態を採用した.

陶材被覆形態に関しては, veneer type は従来より一 般に用いられてきた形態であるが, 最近, 強度的, 審美 的な要求から full bake type も採用されるようになつ ている，陶材が金属に及ぼす影響については，Tuccillo ら 4 (1) の研究報告が示すように, 無視出来ないものであ る. そこで, 陶材の影響, すなわち陶材の被覆度の多少 が，冠の変形に及ぼす影響を検討するために, veneer type, full bake type の 2 形態を採用した.

II. 実験結果について

1. 製作過程における間隙量の変化

i. 鋳造後

鋳造後の間隙量の変化について考察すると, 最も間隙 量の小さい部位は C, D, G で，その值は 15〜30 $\mu$ で あり,この切断面における冠と支台歯は, 側壁下部で主 に近接し，あるいは接触するものと考えられる．また， 部位 $\mathrm{C}, \mathrm{D}, \mathrm{F}, \mathrm{G}$ の間隙量と部位 $\mathrm{A}, \mathrm{B}, \mathrm{E}$ のそれとを 比較すると, 測定方向が歯軸方向に平行に近い部位ほど 大きかつた. このことは, 鋳造後の間隙量の変化は, 歯 軸方向のずれ，すなわちワックスパターンを基淮にして 考えると, 鋳造体の歯軸方向の浮き上がりを意味するも のと考えられる.

鋳造後の浮き上がりの原因としては, 鋳造体の収縮, 変形および冠内面の面あらさが考えられる.このうち, 面あらさに関しては, 予備実験で面あらさの測定を行な つた結果, 中心線平均あらさ $\left(\mathrm{H}_{\mathrm{s}}\right) 4.2 \sim 4.5 \mu$ であつ た. 焼付用金合金の表面あらさに関して, 富永 ${ }^{26)}$ は $\mathrm{H}_{\mathrm{a}}$ 約 2.5 3.0 $\mu$ であつたと報告している. 本予備実験の 結果は, 富永の值よりやや大きい值を示したが,この程 度の表面あらさは，富永も言つているように；適合には さほど影響しない因子と考えられる。

さて一方, 鋳造過程における収縮, 変形は冠の浮き上 
as cast
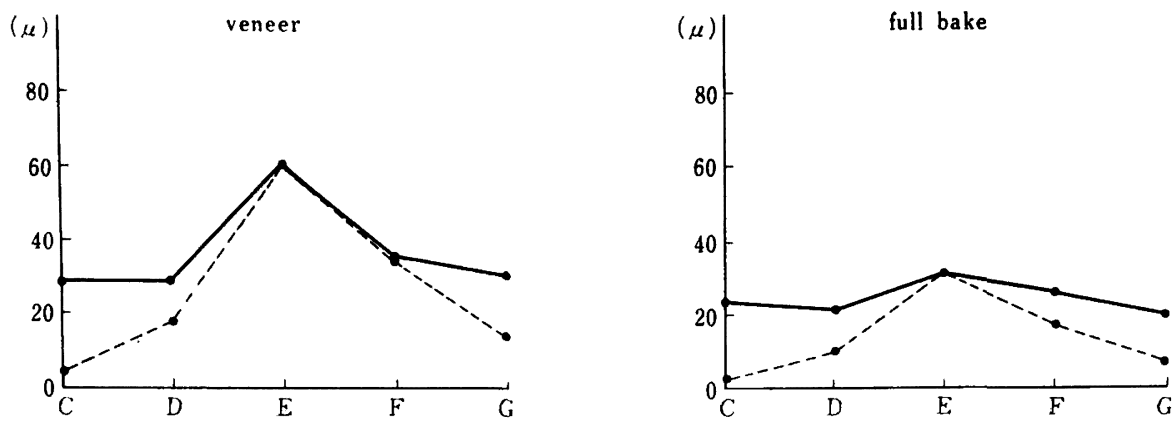

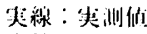

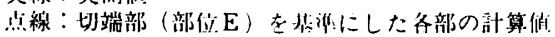

図 16 鋳造後における間除量（実測值と計算值との比較）

がりの主な原因と考えられる，実際，本実験で切端部の 間隙量を浮き上がり量とし，原形がそのまま浮き上がつ たことを想定した場合，側壁部 C, D, F, G の計算値は 点線部のようになり, 実測値と対比させた場合, 部位 $\mathrm{C}$, G において実測值が大きく，計算值との差が大である (図 16). このことからも, 冠が変形したことが明らか である. この収縮, 変形の原因として, 主にワックス操 作時の変形, 埋没材の膨張, 金属の収縮および埋没材の 強度による鋳造収縮抑制のための変形, 金属の厚みの差 による応力のちがいによる変形が考えられる. 特に, 本 実験試料は臨床的であるため形態が複雑であり厚みも各 部で異なる. そのため, 回転させながらワックスパター ンの撤去が可能な単純な円筒形試料に比へると，パター ン撒去の際, 不均一な応力がかかりやすいことが考えら れる. また, 埋没材の膨張が冠の変形に影響を及ぼすこ

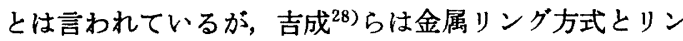
グレス方式との比較を行つた結果，金属リング使用の場 合, 埋没材は開放側一向い粘性流動を起こすため鋳造体 は縦方向に膨張するのに対し, リングレスの場合は埋没 材はあらゆる方向に膨張し, 変形の少ない鋳造体が得ら れると言つている.さらにその膨張は加熱膨張時に顕著 に現われるため, 加熱膨張の大きいセラミゴールド埋没 材の場合, 最も有効であると報告している.また, 野首 42) 適合良好な鋳造銁を得るために，リングレス鋳造が 有効であることを報告している．以上のことから，本実 験においても，埋没材の膨張はほぼ等方性であると考え られる.

鋳造後の間陌量を陶材被覆形態差について考察する と, 側壁部では, 最初の操作である鋳造後すでに veneer type と full bake type の間に差を生した(図14, 16).
これは, veneer type と full bake type の唇舌的な金 属の厚みの相違によるものと考えられる．埋没材の膨張 は等方性であると考えられるが，金属の厚みのちがいに よつて,金属の収縮時の応力,才なわち鋳造応力による変 形が生じたためであろう. veneer type のコーピング では，唇側に比べ厚みの大きい舌側の方が鋳造後の凝固 がやや遅れるため, 舌側で引張り応力が, 唇側で圧縮応 力が生じたことが考えられる. 厚みの差による鋳造体の 変形については, 千々岩43) が鋳物について確かめてい る. 一方, full bake type は唇舌側とも肉厚がほぼ等 しいため，金属の収縮による応力が小さく，不均一な変 形もほとんどなかつたものと考えられる.この事に関し て, 林 ${ }^{25)}$ は両側とも厚みが $0.5 \mathrm{~mm} の$ full bake type の円筒型試料および片側のみ $1.0 \mathrm{~mm}$ の厚みを有した veneer type の円筒型試料について, その浮き上がりを 測定することによつて, 製作過程における冠の膨縮を計 算し検討した結果,鋳造過程では 2 種類の形態の間には, 有意の差は認められなかつたと報告している.このよう に，鋳造体の形態差による適合状態に関しては，高橋30) も円筒型の試料を用いて，林と同様の結果を発表してい る.それらが本実験結果と異なつた理由については, 使 用した試料の形態および測定方法が考えられる.すなわ ち，彼らの実験に用いたパターンは，本実験使用の臨床 的形態と異なり，その内面が完全な円形である.そのた め, 鋳造応力による変形が少なかつたことと，たとえわ ずかな変形があつたとしても，浮き上がりとして有意の 差が生じなかつたことが考えられる.

歯頸部辺縁形態のちがいによる鋳造後の間隙量の差異 について考察する．部位 A，Bにおける間隙量は, shoulder type が最も大であつた. この点に関して, 冠の浮 


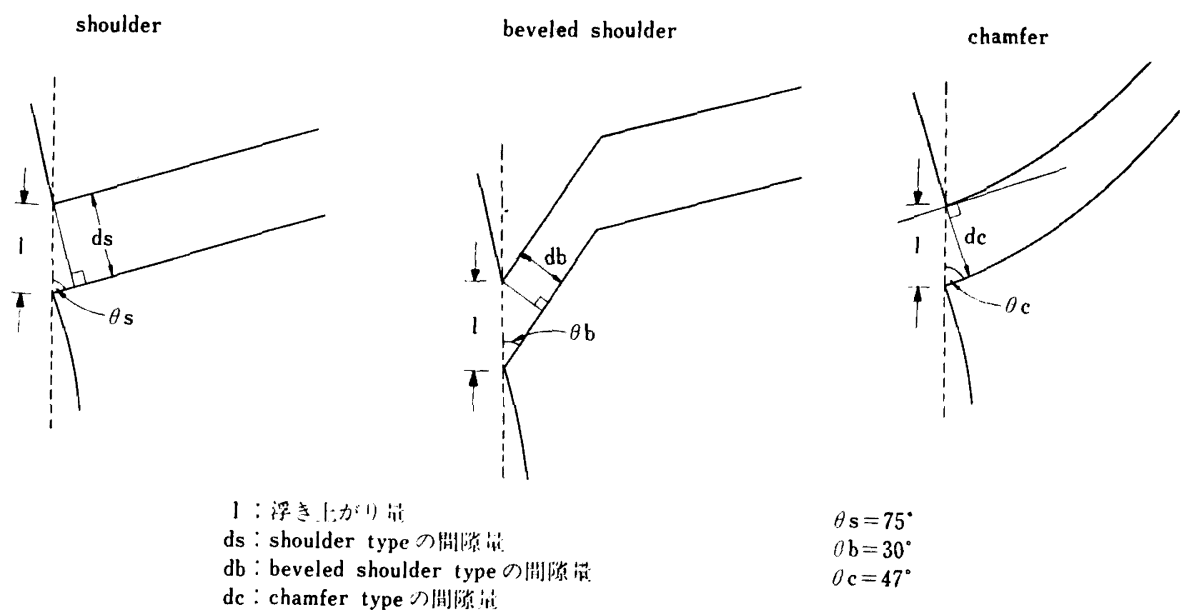

図 17 浮き上がりが同等な場合, 辺縁形態のちがいによる間吵虫の差異

き上がりが同等であると仮定すると，唇面歯頸外縁部の 間隙量は, 幾何学的に

$$
\begin{array}{ll}
\text { shoulder } & \mathrm{d}_{\mathrm{s}}=1 \sin \theta_{\mathrm{s}} \\
\text { beveled shoulder } & \mathrm{d}_{\mathrm{b}}=1 \sin \theta_{\mathrm{b}} \\
\text { chamfer } & \mathrm{d}_{\mathrm{c}}=1 \sin \theta_{\mathrm{c}}
\end{array}
$$

で表わされる.ただしd：間隙量，1：浮き上がり量， $\theta_{\mathrm{s}}$ : shoulder 傾斜角度, $\theta_{\mathrm{b}}$ : beveled shoulder の傾斜角 度, $\theta_{\mathrm{c}}$ : chamfer 歯頸外縁部の傾斜角度とする.ここ で, $\theta_{\mathrm{s}}, \theta_{\mathrm{b}}, \theta_{\mathrm{c}}$ の角度は図に示したごとく $\theta_{\mathrm{s}}=75^{\circ}, \theta_{\mathrm{b}}$ $=30^{\circ}, \theta_{\mathrm{c}}=47^{\circ}$ であるから $\sin \theta_{\mathrm{s}} \doteqdot 0.96, \sin \theta_{\mathrm{b}}=0.5$, $\sin \theta_{\mathrm{c}} \doteqdot 0.73$ となり $\mathrm{d}_{\mathrm{s}}>\mathrm{d}_{\mathrm{b}}>\mathrm{d}_{\mathrm{c}}$ つまり shoulder $>$ ch. amfer > beveled shoulder の順に間隙量が異なつてくる (図 17). しかも本実験では shoulder type の切端部の 間隙量すなわち浮き上がりが最も大であつた. したがつ て以上のことから, 部位 $\mathrm{A}, \mathrm{B}$ の間隙量は shoulder type が最も大きくなつた理由が説明できる.

ii. degassing 後

金属焼付ポーセレン冠は, 臨床上，鋳造後のコーピン グをロ腔内で試適した時は支台歯との適合が良好と思わ れても, degassing 後陶材焼付けを経た後では, 茈頸部 の適合が不良になつていることが指摘 $6,24,25,33,35)$ され， その原因として degassing から缸材焼付け完成までの 過程で, 何らかの変化が起こるものと考えられている.

本実験では, degassing 後側壁部 C, D, F, G の間隙 量は，鋳造後の間隙量に比へ，同等か $10 \mu$ 程度の縮小 的変化が認められた. 冠の側壁部の幅径を $4 \mathrm{~mm}$ とし ても約 $0.25 \%$ 以内の変形が生じたことが考えられる. この点に関して，西村 ${ }^{35}$ や安滕 ${ }^{2-1}$ 门は焼付用合金 KIK について, degassing で $0.1 \%$ 程度，林 ${ }^{25)}$ は約 $0.1 〜$
$0.2 \%$ 程度の変形の生じることを, 基礎的実験でも明ら かにしている. また，C，D， F， G の間隙量の相対的な 変化がやや認められ, 鋳造後は $D, F$ 部に比べ間隙量は C, G の方が小さい傾向が認められたが, degassing 後 では逆に $\mathrm{C}, \mathrm{G}$ 部よりも $\mathrm{D}, \mathrm{F}$ 部の間隙量が小さい傾向 を示した，このことは, degassing による変形にともな つて，支台歯に対する冠の適合状態が変化したことが考 えられる.

部位Aについてみると, chamfer type のみ約 $13 \mu$ 増大したが, 他の形態ではほとんど変化は認められなか つた (図 13-1). その理由として, chamfer typeは shoulder type や beveled shoulder type のように辺 縁部にカラーを付与したものに比へ，歯頸部の金属量が 少ないこと，および形態的に変形抵抗性が小さいことが 考えられ, そのため冠辺縁部が加熱による変形を起こし たものと思われる. 加熱による変形には, 鋳造応力解放 に伴う変形, 自重による creep たわみによる変形などが あり，西村 ${ }^{35)}$ ，安藤 ${ }^{24)}$ らはそのうちでも鋳造応力解放に

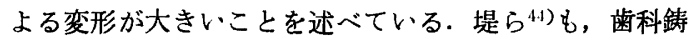
造体の加熱処理による実験で, 残留応力の解放と変形の 増大を確かめている.

鋳造後から degassing 後での部位 $\mathrm{E} の$ 間隙量の変化は veneer type では減少したが, full bake type では増 加した. この変化の差異の原因は, veneer type と full bake type のコーピングの唇舌側の金属の厚みの差に よる変形傾向のちがいが原因と思われる.すなわち， veneer type の部位 $\mathrm{E} の$ 間隙量が減少したのは, 唇舌的 な金属の厚みの差から, 鋳造後, 鋳造応力による不均一 な歪みのため浮き上がりのあつたものが，応力解放によ 
つて歪みが解放され，かえつて適合が良くなつたためと 考えられる. 一方, full bake type では, 金属の厚み がほぼ均一なため, 鉡造後, 冠が内方に向かつて一様に 収縮するものと考えられる.しかし，埋没材によつて十 分な収縮はできず, 残留応力として残つたものが, deg. assing による応力解放にともなつて, 冠内方に向かつて 一様に変形し，それによつて切端部で間隙が生じたもの と思われる.

\section{iii. 陶材焼付け後}

鋳造体は鋳造後の残留応力の大部分が最初の熱処理で ある degassing 時に解放されるために変形し，さらに 陶材焼付け操作によつて新たな応力一ひずみの関係が生 じるものと考えられる．その原因には，陶材収縮時，金 属との熱膨張係数の差による応力に伴なう変形 ${ }^{11,45)}$ ，あ るいは，自重による creep たわみ ${ }^{35,46)}$ などが考えられ る.

本実験において，ことに唇面歯頸外縁部 A では， degassing 後に比へ間隙量の増大傾向が認められた. なかで も, chamfer type で最も大きい変化が認められた. 冠 の遊離端側である唇面歯頸外縁部が，陶材焼成による心 カによつて最も影響を受けやすかつたことが考えられ る. また, 唇面歯頸内側部Bでも degassing 後に比べ 間隙量の増大傾向は認められたが， chamfer type では ほとんど変化がなく, 部位 $\mathrm{A} の$ 変化と対照的であつた. これは chamfer type における部位Bは，Aに比べ冠内 側に位置していること，および shoulder type, beveled shoulder type のBに比へ位置，形状が異なるため間隙 量の変化が非常に小さかつたものと思われる．唇側部は 熱膨張率の異なる陶材と金属との複合体であり, bimetal と同様に温度変化にともなう変形を生じることは十分に 考えられる. 寸なわち，溶融陶材が温度の低下とともに 収縮し, 金属と結合し, その後固相の状態で収縮し, 金属 との熱膨張率の差によつて変形を生じる. Tuccillo ら ${ }^{41)}$ は, 一定の厚さの金属板に種々の陶材を焼付けることに よる板の変形を観察し，金属と陶材の厚さの比率の変化 に応して変形量が異なることを確かめ，その変形量から 陶材と金属間の界面応力を算出している．本実験におけ る 3 種類の辺縁形態のうち chamfer type が著明な間 隙量の変化を示したのは, 陶材収縮による応力とひずみ の関係に対して冠が変形しやすかつたためと推定され る.すなわち, shoulder type, beveled shoulder type に比ベ, chamfer type は歯頸部辺縁形態が曲線的であ り，かつ辺縁部の金属量が少ないことが原因と考えられ る. 山田 ${ }^{17)}$ は金属焼付ポーセレン冠について, shoulder type の唇側辺縁部の金属の厚みを $0.1 \mathrm{~mm}$ と極端に薄 くしたところ，著明な変形を生じたことを報告してい る.このように，金属量の多少が冠の変形に関与するも のと考えられる.一方, beveled shoulder type は, 陶材 焼付け後の唇面歯頸外縁部の間隙量が最む小さかつた. このことは，形態的に bevel を付与したことが，冠の 変形を少なくしたものと思われる.

また，側壁部 C, D, F, G における間隙量は，陶材被 覆形態別の差異が認められた. すなわち, veneer type に比較すると, full bake type の方が間隙量が小さか つた.これは, veneer type では陶材が主に唇面のみに 限られていることと，唇面は舌面に比べ金属が薄いた め, 陶材焼成により発生する応力が冠表面全体にかから ず，冠の変形が不均一となつたことが考えられる.これ に対し，full bake type では，コーピングのほぼ全面 に陶材を焼き付けるため，冠全体に応力が均一にかか り，したがつて不均一な変形を生じなかつたことが推察 される.

\section{iv. セメント合着について}

試適時良好な適合を示す鋳造冠もセメント合着時に浮

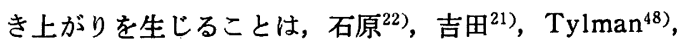
Jones $^{49}$ ， Selberg ${ }^{50)}$ ，らによつて報告されている. 前畨 部の全部被覆冠支台歯形態は，臼歯部に比べ，唇舌的軸 面傾斜度が大きい, 歯冠長が長い, 形態が複雑である, などの点で異なる. そのため浮き上がりに関しても田 部の場合と異なることが当然予想される. セメント合着 による浮き上がりは，支台歯に対する冠の歯軸方向への 平行移動と考えられる. そのため本実験での浮き上がり は測定方向が歯軸方向と一致し，その量が最も顕著に現 われる切端部について検討した. veneer type では, 浮 き上がり量は辺縁形態別の差異はほとんど認められなか つた.これに対し, full bake type では, 辺縁形態別 の差異がかなり認められた（表 8 , 図 12). veneer type と full bake type とで差を生じたのは,前項で述 へたように，支台歯に対する冠の側壁部の間隙量が full bake type と veneer type とで異なるため, 辺縁形態 がセメントの浮き上がりに及ぼす影響も異なつたためと 思われる. 切断面をみると, shoulder type, J beveled shoulder type では, 歯頸部内面で line angle を呈し ているのに比へ, chamfer type は rounded angle を 呈している.また，歯頸部における軸面傾斜度も shoulder type, beveled shoulder type に比へて chamfer type では大きく, セメントの流動抵抗が最も少なかつ たものと思われる. 特に側壁部の間隙量の少ない full 
$82-82$

bake type で辺縁形態差が大きく影響したものと考えら れる. 大藤 (1) らは，全部鋳造冠の支台歯で shoulder type と knife edge type とを比較し, shoulder type の方が浮き上がりが大であつたと報告し, shoulder type がセメントの流動抵抗が大きいためと検討を加えてい る.

本実験における唇面歯顠外縁部のセメント層の厚さ は, 臨床的に重要であるが, 最小のものは beveled shoulder type (veneer type) で $71.5 \mu$ を示し, 最大の ものは shoulder type (full bake type) で $120.5 \mu$ を 示した（図 11）。また，このセメント層の厚さは，veneer type, full bake type ともに shoulder type が最 も大きく, chamfer type がこれにつぎ, beveled shouIder type が最も小さい值を示し，それら 3 者間には有 意差が認められた（表 4)、臨休において，歯頸部が正し く適合するということは，補緅物の具備すべき要件であ るが，これに関して，どの程度の適合状態を実用的とす べきか，また歯周組織を害せず，七メント溶出と 2 次う 触の防止ということが目標であつても，この条件を満た すセメント層の厚さの許容籁囲をどの程度にするかは不 明である，現在の補緅学の常識では，補緅物の辺緣部は， 探針の先がかから程度とすることが目標とされている し臨床上それが可能となつている.52) しかし，このよう な状態というのは冠辺緑をバーニッシュすることによつ てのみ得られるものであつて, 特に, 歯肉縁下に辺縁を 設定した鋳造体では,セメント合着しただけでは,良好な 適合度を得ることは困難である.本実験において，冠と 支台歯間に介在するセメント層の厚さは, 測定部位によ

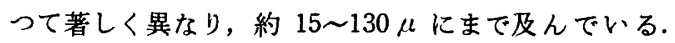
この原因として，第一に冠と支台歯歯面との間隙がセメ ント合着前の試適時にすでに不平均であること, 第二 に, セメント合着によつて, 冠と支台歯との関係に歯軸 方向のずれ，すなわち浮き上がりが生じるため，各部で 間隙量の変化量が異なることなどが考えられる.特に, 側壁部においては, セメント層が薄く, $20 \mu$ 前後の厚 さのものも認められたが，この值は一般に言われている

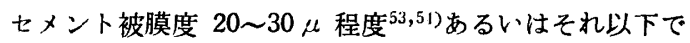
あることを示している．セメント合着の際，冠を支台苗 に雨入し始めるときセメントは何ら抵抗なく流出する が, 插入するにつれて, 軸面傾斜度の小さい部位ほど冠 内面と支台歯表面とが早く近接し，その部位でセメント の流動抵抗を生じはめる。唇舌的には。側壁下部の C, Gで最も流動抵抗を生じやすかつたことが推察される.

2. 陶材焼成により発生する応力および唇面菌頸部辺

\section{縁形態別の変形抵抗性 \\ i. 陶材焼成により発生する応力}

金属焼付ポーセレン冠と全部錆造冠との大きい相違点 は，陶材烧成の有無である. そのため, 金属焼付ポーセ レン冠の適合性を論じるとき, 陶材烧成の問題を考える 必要がある.金属と陶材とは異質の材料であつても，両 者は高温下でぬれを生し，常温で強固に結合する．金属 と陶材とは熱膨張の程度がわずかに異なるため, 結合体 内部で応力ーひずみの関保が生し，その際，金属が変形 することが考えられた. 応力ーひずみの問題を考える上 において，陶材焼成後陶材内に残留する㐫力を知ること は重要であると思われる，陶材が冷却する間に発生する 応力注，陶材および金属がかなり高温にある状態での塑 性流動あるいはクリープ変形などによつて大部分緩和さ れるものと予想されるにもかかわらず, 基硙実験の結 果, 室温まで泠却された後においても, これ程大きな応 力が残留していることは注目に值する(図 15).この残 留応力は, 陶材焼付け後における金属の変形を生じる大 きな要因として考虑に入れるべきである.陶材焼成によ り発生する応力の影響は, 冠の遊離端側である唇側辺緑 部で受けやすく, 従ってその部分に変形を生じやすいこ とが推測される.

ii. 唇面歯頸部辺縁形態別の変形抵抗性

光弾性実験をはじめとして, 歪ゲージ法, 応力塗料法, 反射光弾性法, モアレ法など応力ーひずみ測定法の蒾科 への導入が試みられてきた. 著者も本研究に歪ゲージを 使用した. 種々の応力ーひずみ測定法は表面ひずみを測 定するものがほとんどであるため，現象を内部で，ある いは全体的に把握するには不便である. できれば，実物 そのものについての実験, 測定が望ましいことはいうま でもないが, 種々の制約のため, 従来の研究はそのほと んどが実物を模做した模型について行われている. 模型 実験を行う際留意しなければならないことは，実物に等 価な模型あるいは実物と相似の模型を設定することであ る.これは形態など幾何学的条件はもちろんのこと, ヤ ング率など物理量について考虑する必要がある. 模型実 験の代表的な方法である光弾性実験法は, 内部の応力分 布を知ることはできるが，複雑な形態の三次元模型を蔽 作する際, ヤング率, ポアンン比などを相似させるのが むずかしい。

有限要素法といわれる数値解析法は, 1950 年 Turner らにより構造力学の分野に用いられたのが最初といわれ くおり, 近年の電子計算機の発達とともに飛躍的に発展 した方法である.この方法では, 複雑な形態を模式的に 
近似することができ，種々の外力による問題を扱うこと ができる.また, 荷重条件, 拘束条件を任意に選ぶこと ができる.このように, 有限要素法は, これまでの数值 解析法あるいは実験的方法に比べて多くの長所を有して いるので，現在，実用的な構造解析法として㑢光をあび ている.

金属烧付ポーセレン冠の製作過程のうち，陶材焼成に より発生する応力については，著者は，基整的に平板試 料について，大きい残留応力の存在を確かめることがで きた. 一方, 冠は辺緑部が最も変形しやすい部分である ことは十分に考えられる. しかも，冠辺縁部は臨床的に 非常に重要であり，その部位の変形の少ないことが要求 される. 本実験試料そのものについて，応力ーひずみの 関係を実際に計測するのは非常に困難である。そのた め, 実物に相似の 20 倍拡大図について，有限要素法を 用い，歯頸部における応力ーひずみを計算することによ つて, 変形抵抗性を定性的に検討した。

要素数は多いほど精度が良く好ましいものであるが， 計算機の能力にも限界があり，制約を受ける. 本実験は， 辺縁形態別の変形抵抗性を定性的に比較検討するために 行つたものであり，そのため，著者の行つた要素分割方 法の範囲でさしつかえないものと考える. 計算の結果, chamfer type $<$ shoulder type $<$ beveled shoulder type の順に変形抵抗性が大きいことがわかつた。 なお, 要素 分割モデルに用いたコーピング切断面の搪大図上で, 唇 側辺縁部に扔ける面積を計測した結果, shoulder type は約 $462 \mathrm{~mm}^{2}$, beveled shoulder type は約 $405 \mathrm{~mm}^{2}$, chamfer type は約 $278 \mathrm{~mm}^{2}$ であつた. 実物の唇側边 縁部の面積は，1/400 倍して, shoulder type は約 1.16 $\mathrm{mm}^{2}$, beveled shoulder type は約 $1.01 \mathrm{~mm}^{2}$, chamfer type は約 $0.70 \mathrm{~mm}^{2}$ である.すなわち, chamfer type は，辺緑部の金属量は最も少なく，その形態が平板に近 い单純形態ゆえに，力学的に変形抵抗性が最も小さいこ とがわかる. 一方, beveled shoulder type は辺緣部の 金属量法, shoulder typeよりも少ないが, shoulder type より大きい変形抵抗性を認めたのは, bevel の付 与が辺緑部の補強的効果をあらわしたものと考えられ る.

これらのことは, 製作過程で生じる応力に対する辺縁 形悲の種類による変形抵抗性の差異を明らかに示すもの である.

以上各項目ごとの考察を行つてきたが，ここで，それ らを総合して補緅学的立場から考察を加えることにす る.
鋳造後, 唇面歯頸外縁部の間隙量が大きく現われた。 これは主に鋳造収縮によるものであり，鋳造操作を行う 限り避けられない問題である. すなわち, veneer type と full bake type の側壁部の間隙量が異なつたことか らみても，鋳造収縮による応力がその影響的因子と考え られる. 次の degassing 操作によつて, 唇面蒌頸部, 側壁部ともに間隙量のわずかな減少が認められた.これ は鋳造後の残留応力の解放および高温での金属の自重に よる塑性変形が考えられる. そのため degassing 後は， コーピング内の応力の残留はほとんどないものと思われ る.さらに，陶材烧付けによって再び間隙量の增大が認 められた. 特に chamfer type の唇面歯頚外縁部で間 隙量が大きく増大した。これは，陶材焼成により発生し た応力によつて, 冠辺縁部の金属の変形を生じたものと 思われる。なお，陶材焼成による応力一ひずみの存在 は，平板による実験でも確かめ得た。また， chamfer type の間隙量の増大は, 有限要素法による変形抵抗性 の結果とも類似した傾向を示すものである. 陶材燒付け によって生じる変形は，金属の硬さ，特に高温において 陶材を烍付ける際の, 硬さの不足が原因の一つと考えら れる. 本実験に使用した金属 KIK の硬さは，常温で約 $\mathrm{H}_{\mathrm{v}} 140$ であるから, 高温時では, 非常に軟らかいもの と想像される. その対策として, 今後, 高温における陶 材焼付け操作に十分耐えうる金合金の開発が必要であ る. 他方, 金合金に比べ硬度の大きい $\mathrm{Ni}-\mathrm{Cr}$ 系の卑金 属合金の臨床応用が期待される，卑金属において，鋳造 後の良好な適合が得られるようになれば，比較的薄い金 属の使用が可能となるであろうし，そのため歯質の削除 量も少なくてすむであろう。つぎに，七メント合着によ る冠の浮き上がりは非常に重要な問題であり, 辺縁部の セメント層の大小は補緅物の価值を左右する．本実験に おいて，セメントの影響は唇面歯頸部，切端部，敗壁部 における数值からみても明らかである. 特に唇側辺縁部 では，セメント層の厚さが約 $70 \sim 120 \mu$ となつた。 この 值は，全部鋳造冠のセメント層に比べて，決して良好な 値ではない。このことからも，今後，セメント合着にお いて，有効な浮き上がり防止策を検討することが必要で あることがわかつた。また，歯頸部の間隙量を小さくす るためにも，臨床的に支台莉のリリーフ等の工夫が必要 であろう。

さらに，支台歯の唇側碀頸部辺緣形態ならびに冠の罂 材被覆形態について述べる.

shoulder type は従来より，最も多く採制されてきた 形態であり，技術的に歯肉縁下の形成は比較的容易であ 
り, shoulder 愊あるいは蒾肉縁下の梁さをコントロー ルしやすい，また， shoulder 辺縁は明瞭であり，技工 操作の上でトリミングは比較的容易でかつ正確にできる 利点を有する. また, shoulder type では, コーピング 辺縁の断面の形態は, 垁験結果からも力学的に変形抵抗 性の比較的大きい形態であることがわかつた.しかし， 冠全体の浮き上がりによる間隙量がそのまま唇面歯頸外 縁部に生じやすいことや，軸面との間で line angleを 呈するため, セメント合着時のセメントの流動抵抗が大 きくなり，浮き上がりに影響を及ぼすことが考えられ る.

beveled shoulder type は, 形態的には, shoulder に bevel を付与したものであるが, 歯肉縁下に bevel を形 成しなければならないことからも， shoulder type の形 成に比較すると, 辺縁が歯肉縁下に梁く入りすぎる危検 性があり，正確な形成は技術的にやや困難である. 橋本 ら ${ }^{38)}$ は，歯肉の損傷の少ない beveled shoulder type の 形成法を報告しているが，その中で，技術的な習熟の必 要性を説いている. 他方, 形態的には, shoulder type にさらにカラーを付与するため, 製作過程での変形は少 なく, 有限要素法による数值計算結果からも, 力学的に 変形抵抗性が最も大きいことがわかつた。 セメント層の 縮小対策としても, bevel の付与は有効である.

chamfer type は, shoulder type, beveled shoulder type に比べ，断面をみるとすべて曲線で構成されてお り, 全部鋳造冠辺緑の形成に準じて行えばよいが，歯肉 縁下の梁さのコントロールは困難であり, 辺縁は鎕苗状 を呈しやすく，崡肉損傷の危険性も大きい. 金属焼付ポ 一七レン冠の唇面崡頸部辺釈形態として chamfer type を用いる時, 陶材の入るスペースを考えた場合, shoulder type や beveled shoulder type に比べると, 辺 縁部の金属量が十分に確保できない，そのため，本研究 結果において chamfer type の変形抵抗性が最も小さ かつた. 一方, chamfer type の歯頸部断面が曲線的で あることから，七メント合着時のセメントの流動抵抗が 小さく, そのため冠の浮き上がりが少なかつたものであ ろう.セメントの流動抵抗を小さくするためには, shoulder type や beveled shoulder type においても, line angle を呈する軸面下部を rounded angle にすること は有効であると思われる.

陶材被覆形態に関して, veneer type に比べると, full bake type は, 製作過程を通じて, 冠と支台歯間 の間隙量が特に側壁部では小さく, 小法変化の点で安定 していた. 寸なわち適合度の面からは, full bake type
が良いことがわかつた，また，臨床的に，舌面の耐摩耗 性，審美性它考虑しても，veneer typeに比へ優れてい るように思われるが, 唇舌的な厚みの薄い歯牙の場合, あるいは対合歯切端とのクリアランスが十分得られない 場合は，舌面の削除量が不足するため, full bake type が適用できなくなる.これら full bake type が適用で きない場合は, veneer type を採用しなければならな w.

以上にもとゔいて，金属焼付ポーセレン冠の唇面歯频 外縁部の適合度, 冠内面の適合度, 七メント合着による 浮き上がり, 唇面歯頸外縁部におけるセメント層などの 諸点から臨床的に判断すると, 歯頸部辺縁形態は beveled shoulder type とし, 陶材被覆形態は full bake type を採用することが, 最も良い冠の適合状態を得る ための当面の対策法と考えられる.

\section{総括および結論}

支台歯に対する人工歯冠の良好な適合条件を確立する ための研究の一環として, 金属焼付ポーセレン冠につい て, 各製作過程における冠の適合状態を解明することを 目的として, 歯頸部辺縁形態ならびに陶材被覆形態の差 異が冠の適合性に及ぼす影響を検討した.ささらに陶材焼 成により発生する応力および唇面歯頸部辺縁形態別の変 形抵抗性についても合わせて検討し, 次の結果を得た.

1. 各操作過程における変化: 鋳造後, 鋳造収縮によ り生じると考えられる間隙量が認められ, 唇面歯頸外縁 部の間隙量が最も大きかつた. degassing 後の間隙量 は, 鋳造後に比べやや小さくなつた. この変化は, 主に 鋳造応力の解放によるものと考えられる.さらに, 陶材 焼付け後の間隙量は, degassing 後に比べ明らかな増大 を示した.これは, 陶材焼付けにより冠の変形が生じた ためと推定される.

2. 歯頸部辺縁形態のちがいによる間隙量の差は, 製 作過程を通じて主に唇面歯頸部で認められ, 陶材被覆形 態のちがいによる間隙量の差は, 主に側壁部で認められ た.

3. 唇面歯頸外縁部の間隙量について, 辺縁形態別に 比較すると, shoulder type の間隙量は鋳造後すでに他 2 者に比べて最も大きく, セメント合着による浮き上が りも最も大きかつた. chamfer type の問陌量は，陶材 焼付け後著しく増大し, セメント合着後では, shoulder type についで大きいことが認められた. beveled shou. Ider type の間隙量は, 鋳造後からセメント合着後まで 
最も小さかつた

4. 側壁部の間隙量について, 陶材被覆形態別に比較 すると, full bake type は, veneer typeに比べて間 陌量が小さく適合性の良好なことが判明した。 この差異 は、コーピングの形態差にもとずく冠の変形のちがいと して䤲造後すでに生じておりセメント合着後も同様の傾 向として認められた。

5. 陶材焼成に上り生じる応力の残留が確かめられ た.この残留応力は, 陶材焼成後における鋳造体の変形 を生じる大きな要因と推定される.

6. 陶材焼成後における唇面萪頸外縁部の間隙量の測 定結果からみて shoulder type, beveled shoulder type に比べ, chamfer type の方が変形を受けやすいことが 推測された.

7. 有限要素法によると, 唇面菌頸部辺縁形態別では chamfer type が最も変形しやすく, ついで shoulder type, beveled shoulder type の順となつた.

以上の結果，金属焼付ポーセレン冠の適合性に対し て，陶材焼付けによる冠の変形が大きく関与しているこ とが判明した．つぎに，製作過程における冠の変形を少 なくして適合度を良好にするためには，歯㹕部辺縁形態 は, shoulder type およびchamfer type よりも, bev. eled shoulder type にする方が良く，陶材被覆形態は veneer type よりも full bake type にする方が良いこ とが明らかとなった．さらに，冠辺縁部におけるセメン 卜層の厚さを小さくし適合度を良好にするためには, 現 在多く用いられている shoulder type は良くないこと が確認された。

稿を終るに臨み, 本研究に際して, 終始御愁䉆なる御指導, 御校閱を睗わつた大阪大学药学部補緅学第 1 教室下総高次教授 に深く感噼いたします。また，愁切な御教示と御校閲をいただ きました本学理工学教宣山賀礼一教授に愿く御礼申しあげます。 あわせて，日頃から御助言，御助力いただいた丸山剛郎助教授 をはじめ菊科補緅学第 1 教室および歯科理工学教室の諸先生に 䔆んで感謝の意を表しま寸。

なお本研究の要旨の一部は第 61 回日本補緅菌科学会（1974年 11月16日）に执いて発表した。

\section{文献}

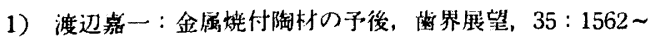
1567, 昭和 45 (1970).

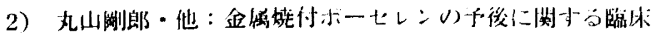
的研究，第 3 報; 患者リコールによる診查結果について，
補緅誌, $16: 387 \sim 401$, 昭和 48 (1973).

3）丸山剛郎・他：金属焼付ポーセレンの予後に紩古る踟床 的研究, 第 4 報; 歯肉変化と適合性との関連性, 補絽誌, $17: 16 \sim 20$ ，呚和 48 (1973).

4）黑江良治・他：支台歯辺縁部の形態の差異に依る全部鋳 造冠の寸法䞍度，歯学，55:64，昭和 42 (1967).

5）橋本 収：銤造冠の支台歯形態に関寸万実験的研究一浺 面傾斜度ならびに歯頙部辺縁形態について一, 補緅誌, $16: 24 \sim 44$, 昭和 47 (1972).

6) Shillingburg, H.T., Hobo, S. and Fisher, D.W. Preparation design and margin distortion in porcelain-fused-to-metal restorations, J. Pros. Dent., 29 : 276 284, 1973.

7）多和田泰一，横塚繁雄：ポーセレン・クラウン・ブリッ ジ, 東京, 昭和 43 , 医蕃薬出版。

8) Brecker, S.C. : Porcelain bake to gold--a new medium in prosthodontics, J. Pros. Dent., 6: $801 \sim 810,1956$.

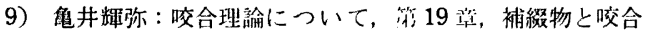
理論, 日本歯技, $71: 12 \sim 31$, 昭和 50 (1975).

10）佐藤 潔：前歯用金属哑付 Porcelain crown の破折 強度に関寸る研究，歯科学報， $71: 886 \sim 909$, 昭和 46 (1971).

11）小山捷三：小臼蔽に㧈ける金属焼付前装 crown の破折 強度に関寸る研究，歯科学報， $73: 310 \sim 332$, 別和 48 (1973).

12）藤田恒太師：蔽の解剖学, 東京, 炤和 39 , 金原出版.

13）上条雅楌：日本人永久蔽の解剖学, 東京, 㕻和 37 , 地人 萣管.

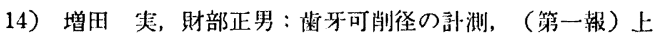
顎中切歯, 齿科学報, $52: 27 \sim 31$, 炤和 27 (1952).

15) Johnston, J.F., Mumford, J. and Dykema, R.W. : Modern practice in dental ceramics, Philadel. phia and London, W.B. Saunders. Co., 1967.

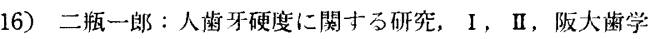
誌, $4: 1 \sim 20,177 \sim 181$ ，昭和 34 (1959).

17) Strausberg, G., Katz, G. and Kuwata, M. : Design of gold supporting structures for fused porcelain restorations, J. Pros. Dent., 16:928 936, 1966.

18) Mumford, G. : The porcelain fused to metal re storation, Dent. Clin. North. Am., March, 241 $\sim 249,1965$.

19) Dunkin, R.S. : A simplified method for multiple wax pattern duplication, J. Pros. Dent., $27: 217$ $\sim 220,1972$.

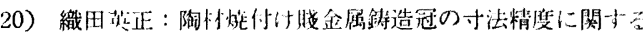




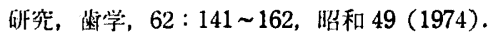

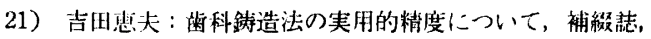
$2: 159 \sim 182$, 炤和 33 (1958).

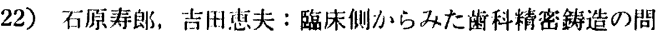
題点, 理工誌, $1: 18 \sim 27$, 弨和 35 (1960).

23）住井俊夫：ワックスパターンの調整方法上精度に関寸る 研究, 理工誌, $12: 54 \sim 71$, 炤和 46 (1971).

24）安藤進夫・他：市販ボーセレン焺付用金合金の烧成時に おうける変形, 理工誌, $13: 237 \sim 248$, 昭和 47 (1972).

25）林詔一郎：陶材炲付け贵金属鋳造冠の寸法精度に関する 俳究，歯学, $60: 536 \sim 557$, 昭和 47 (1972).

26）富永有德：陶材娔付什用貴金属鋳造冠の寸法精度に関寸 る研究一寸法精度上表面あらさに及ぼすリングの加熱速 度と最終加熱温度の影艟一歯学, $62: 255 \sim 275$, 昭和 49 (1974).

27）川原春幸：金属暗付陶材につい下，歯界展望，38:745 ７55，照和 46 (1971).

28）吉成正堆・他：リングレス鋳造法による鈛造精度，橉科 学報, $75: 986 \sim 993$, 昭和 50 (1975).

29）颠坂信夫：ワンピースキャストブリッジの鋳造精度に䦔 寸る研究，紧科学報， $70: 725 \sim 758$ ，昭和 45 (1970).

30）高橋重雄：ポーセレン接付用合金の鋳造，DE 18：4～ 15, 炤和 46 (1971)

31）鿇田篤美・他：歯冠上歯肉の形態に関寸る統計的钼察， 阪大蒌学誌， $13: 371 \sim 379$, 昭和 43 (1968).

32）池田博・他：金属焼付ポーセレンクラウンの有限要絭 法による力学的研究, 補緅誌, 19 (投稿中).

33) Silver, M., Klein, G. and Howard, M. : An evaluation and comparison of porcelain fused to cast metals, J. Pros. Dent., $10:$ 1055 1064, 1960.

34) Shelby, D.S. : Practical considerations and designs of porcelain fused to metals, J. Pros. Dent., $12: 542 \sim 548,1962$.

35）西村文卡，野本直：陶材煤付用合金の熱処理による寸法 変化について, 歯材器誌, $21: 35 \sim 39$, 昭和 45 (1970).

36）保母須弥也：オーラルリハビリテーショ之，東京，㗁和 43 , 䀢歯薬出版.

37）保母須弥也：金属㜔付ポーセレン，東京，昭和42，医蒋 澡出版.

38）橋本収・他：Beveled shoulder type の支台菌形成法 につい下，補緅誌，17:6９，昭和 48 (1973).
39) J $\phi$ rgensen, K.D.: The relationship between the retention of cemented veneer crowns and crushing strength of the cements, Acta. Odont. Scand., $25: 355 \sim 359,1967$.

40）吉田恵夫・他：セメント合着による鏻造冠の浮き上がり について：第一報,金属原型使用の場合,補緅誌， $4: 157$ $\sim 161$ ，昭和 35 (1960).

41) Tuccillo, J.J. and Nielsen, J.P. : Shear stress measurement at a dental porcelain-gold bond interface, J. Dent. Res., 51 : 626 633, 1972.

42）野首孝闵：鋳造鈎の製作過程における寸法変化とその適 合性について，補緅誌，18:363 381, 昭和 50 (1975).

43）千々岩健览：銤造応力の研究，第一報，鋳物，27:247 $\sim 255$, 昭和 30 (1955).

44) Tsutsumi, S. et al. : X-ray residual stress meas. urement of dental castings, J. Osaka Univ. De nt. Sch., 15 : (in press).

45）野口八九重・他：ボーセレン烧付用金属在テストする, D E , $18: 18 \sim 27$, 炤和 46 (1971).

46) Tuccillo, J.J. and Nielsen, J.P. : Creep and sag properties of a porcelain-gold alloy, J. Dent. Res., $46: 579 \sim 583,1967$.

47）山田㴊人：陶材熔着銤造冠の適合精度について一製作過 程に㧍ける問題点一, 歯科技工, $3: 11 \sim 19$, 昭和 50 (1975).

48) Tylman, S.D.: Theory and practice of crown and fixed partial prosthodontics, St. Louis, 1970, The C.V. Mosby Co.

49) Jones, R.R. : A full gold crown, cast and readapted, J.A.D.A., 34 : 605 606, 1947.

50) Selberg, A. : A full cast crown technic, J. Pros. Dent., $7: 102 \sim 122,1957$.

51）大藤幸司・他：各種弾性印象材に上る銶造冠の適合性, 歯材器誌, $30: 123 \sim 127$, 昭和 48 (1973).

52）保丹須弥也，松本清弘：鋳造冠のマージンの適合性につ いて, 歯界展望, $43: 731 \sim 739$, 睸和 49 (1974).

53）高棉重雄・他：合着用材料をテストする，D E， $26: 12$ $\sim 23$, 昭和 48 (1973)

54）增原英一・他：合着材としてのリン酸雨鉛セメントとカ ルボキシレートセメント，DE， $24: 34 \sim 39$, 昭和 48 (1973). 